\title{
A Study of Cathodoluminescence and Trace Element Compositional Zoning in Natural Quartz from Volcanic Rocks: Mapping Titanium Content in Quartz
}

\author{
William P. Leeman, ${ }^{1, \star}$ Colin M. MacRae, ${ }^{2}$ Nick C. Wilson, ${ }^{2}$ Aaron Torpy, ${ }^{2}$ Cin-Ty A. Lee, ${ }^{1}$ \\ James J. Student, ${ }^{3}$ Jay B. Thomas, ${ }^{4}$ and Edward P. Vicenzi ${ }^{5}$ \\ ${ }^{1}$ Department of Earth Science, Rice University, 6100 S. Main St., Houston, TX 77005, USA \\ ${ }^{2}$ Microbeam Laboratory, CSIRO Process Science \& Engineering, Clayton Laboratories, Gate 1, Normanby Road, \\ Clayton, Victoria 3168, Australia \\ ${ }^{3}$ Department of Earth and Atmospheric Sciences, Central Michigan University, 314 Brooks Hall, Mount Pleasant, \\ MI 48859, USA \\ ${ }^{4}$ Department of Earth \& Environmental Sciences, Rensselaer Polytechnic Institute, 110 8th St., Troy, NY 12180, USA \\ ${ }^{5}$ Smithsonian Institution, Museum Conservation Inst., 4210 Silver Hill Rd., Suitland, MD 20746, USA
}

\begin{abstract}
This article concerns application of cathodoluminescence (CL) spectroscopy to volcanic quartz and its utility in assessing variation in trace quantities of Ti within individual crystals. CL spectroscopy provides useful details of intragrain compositional variability and structure but generally limited quantitative information on element abundances. Microbeam analysis can provide such information but is time-consuming and costly, particularly if large numbers of analyses are required. To maximize advantages of both approaches, natural and synthetic quartz crystals were studied using high-resolution hyperspectral CL imaging (1.2-5.0 eV range) combined with analysis via laser ablation inductively coupled plasma mass spectrometry (LA-ICPMS). Spectral intensities can be deconvolved into three principal contributions $(1.93,2.19$, and $2.72 \mathrm{eV})$, for which intensity of the latter peak was found to correlate directly with $\mathrm{Ti}$ concentration. Quantitative maps of $\mathrm{Ti}$ variation can be produced by calibration of the CL spectral data against relatively few analytical points. Such maps provide useful information concerning intragrain zoning or heterogeneity of $\mathrm{Ti}$ contents with the sensitivity of LA-ICPMS analysis and spatial resolution of electron microprobe analysis.
\end{abstract}

Key words: cathodoluminescence, LA-ICPMS, titanium, quartz

\section{INTRODUCTION}

It is well documented that natural quartz samples can have wide concentration ranges for many trace elements (e.g., Ti, $\mathrm{Al}, \mathrm{Li}, \mathrm{Fe}, \mathrm{K}$, contents may vary from sub-ppm up to several hundred ppm; see references cited below), depending on conditions and mode of formation. For example, hydrothermal "vein" quartz associated with various types of ore deposits often has distinctive ranges of $\mathrm{Ti}, \mathrm{Al}$, and other elements reflecting specific compositions and temperatures of associated mineralizing or metamorphic fluids (Holness \& Watt, 2001; Monecke et al., 2002; Müller et al., 2003a, 2003b, 2010; Götze et al., 2004; Landtwing \& Pettke, 2005; Rusk et al., 2006, 2008, 2011; Lehmann et al., 2009). Ti contents in metamorphic and igneous quartz samples also display significant ranges and vary with inferred crystallization temperature or other factors (Suttner \& Leininger, 1972; Watt et al., 1997; Müller et al., 2002, 2003a; Götze et al., 2005; Student et al., 2006; Sato \& Santosh, 2007; Wark et al., 2007; Wiebe et al., 2007; Leeman \& Lee, 2008; Shane et al., 2008; Campbell et al., 2009; Kohn \& Northrup, 2009; Larsen et al., 2009; Spear \& Wark, 2009; Storm \& Spear, 2009; Vazquez et al., 2009; Girard \& Stix, 2010; Huang \& Audétat, 2012; Matthews et al., 2012). Numerous workers

Received March 16, 2012; accepted August 21, 2012

${ }^{\star}$ Corresponding author. E-mail: leeman@rice.edu have demonstrated the efficacy of cathodoluminescence (CL) spectroscopy in documenting the existence and details of such compositional variations in quartz (and other minerals), as well as a correlation between Ti content and relative spectral intensity (e.g., Mason, 1987; Marshall, 1988; Götze et al., 2001; Peppard et al., 2001; Landtwing \& Pettke, 2005). However, quantitative use of CL intensity data is limited owing to uncertainties in their dependence on specific compositional and/or structural details. Other considerations include the difficulty in obtaining high-precision CL intensity data. For example, it is well known that CL intensity generally is a function of sample surface condition and (for certain materials) decreases with time of electron exposure (Luff \& Townsend, 1990; Müller et al., 2003b; Mason et al., 2005). Furthermore, CL spectra comprise contributions from numerous emission bands, many of which originate from structural defects and the presence of diverse trace impurities other than Ti (Perny et al., 1992; Stevens-Kalceff \& Phillips, 1995; Müller et al., 2003b; Stevens-Kalceff, 2009).

Evaluation of elemental contributions to CL spectral intensities has primarily benefited from application of microbeam techniques, as bulk analyses of quartz may be compromised by the presence of mineral or fluid inclusions (cf. Götze et al., 2004). Electron microprobe analysis (EMPA), secondary ion mass spectrometry, and laser ablationinductively coupled plasma mass spectrometry (LA-ICPMS) 
are now commonly used for trace element analysis of quartz and other minerals (Flem et al., 2002; Ulrich et al., 2009; see references above) and are variably effective depending on concentration levels, sample size, and other factors. However, due to limited access to these instruments, consideration of analytical precision, spatial resolution, and detection limit in some cases, and analytical cost, it is desirable to improve on the quantitative application of CL spectroscopy for mapping Ti concentration in quartz. Another advantage is that such maps provide two-dimensional information on spatial distribution, with micron scale resolution, that benefits interpretation. This article summarizes our efforts in this direction, following an approach analogous to that of MacRae et al. (2005, 2008, 2009), who investigated the utility of CL spectra in mapping distributions of rare-earth elements (REE) in the mineral scheelite at trace concentrations ( $\leq$ ppm levels).

The present work was motivated by the experiments of Wark and Watson (2006), who first demonstrated a systematic correlation between Ti content in quartz and temperature of its formation from silicate melts at 1.0 GPa pressure. Application of their "Ti-in-quartz" (or TitaniQ, for short) geothermometer to natural quartz-bearing igneous rocks provides a new tool to evaluate crystallization temperatures and thermal histories of silicic magmas. In subsequent experiments, Thomas et al. (2010) demonstrated that $\mathrm{Ti}$ concentrations in quartz also exhibit significant pressure dependence, and they formulated a "PTitaniQ" thermobarometer that ideally can provide additional constraints on pressure (i.e., depth) of silicic magma reservoirs in the Earth's crust. Huang and Audétat (2012) confirmed a pressure dependence and also documented that Ti solubility in quartz increases with crystal growth rate and with trace concentrations of Li and $\mathrm{Al}$; an empirical thermobarometer based on their experiments differs from that of Thomas et al. (2010). Application of this approach depends in detail on additional parameters - in particular, the thermodynamic activity of $\mathrm{TiO}_{2}$ component in the melt or fluid from which quartz precipitates. Problems with quantification of this parameter have been discussed extensively in recent articles (Ghiorso \& Gualda, 2011; Thomas \& Watson, 2012; Wilson et al., 2012). Although detailed interpretation of Ti variations in quartz is at an early stage of development, the recognition of complex compositional zonation in many natural quartz samples implies variably complicated growth histories that depend strongly on the specific geologic context for each sample. Here, we present a useful means of quantitatively assessing the natural variations and briefly discuss some implications of these data for magmatic processes.

\section{Methods and Materials}

\section{Samples}

The rationale for this study is to combine measurements on both natural and synthetic quartz samples for which there exists sufficient characterization to quantitatively evaluate the significance of observed Ti variations. Table 1 provides basic sample information that is elaborated further below.

The geologic aspect of this work stems from a reconnaissance investigation of natural quartz phenocrysts from rhyolitic rocks of the Snake River Plain (SRP)-Yellowstone volcanic province, southern Idaho, and adjacent Wyoming (cf. Bonnichsen et al., 2008; Leeman \& Lee, 2008). These crystals formed in slowly cooling silica-rich magmas within crustal reservoirs. Considering petrologic and geophysical constraints, Leeman et al. (2008) inferred that these magmas formed at depths of approximately $10 \mathrm{~km}$, which is rather shallow in the crust, due to injections of hotter basaltic magmas at these depths. This notion is supported by experimental studies of Almeev et al. $(2009,2012)$, who experimentally replicated mineral assemblages in two SRP rhyolites at relatively low pressures (ca. 2-4 kbar; equivalent depths between $5-10 \mathrm{~km})$, elevated temperatures $\left(>900^{\circ} \mathrm{C}\right)$, and low water contents $\left(<1.5 \% \mathrm{H}_{2} \mathrm{O}\right)$. It is likely that these conditions correspond to the uppermost portion of a larger magmatic system such as that currently below the Yellowstone caldera (cf. Smith et al., 2009).

Eruption of such magmas between ca. 12 to $0.1 \mathrm{Ma}$ produced large pyroclastic deposits and rhyolite lavas. In addition to quartz, these rocks contain other primary phenocrysts (including ortho- and clinopyroxenes, alkali feldspar, plagioclase, magnetite, and ilmenite) for which independent two-pyroxene, two-feldspar, and two-oxide geothermometers have been developed. Applications of these geothermometers (cf. Honjo et al., 1992; Andrews et al., 2009; Cathey \& Nash, 2009; Vazquez et al., 2009; Ellis \& Wolff, 2010) suggest magmatic temperatures between ca. $800-1,000^{\circ} \mathrm{C}$ for most samples, with values approaching $1,100^{\circ} \mathrm{C}$ in some cases. Such high temperatures are generally consistent with the absence of hydrous minerals (amphibole, biotite) in nearly all rhyolites from this province (cf. Honjo et al., 1992; Cathey \& Nash, 2004; Ellis \& Wolff, 2012). Most samples selected for investigation have been characterized for mineral chemistry and thermometry, which facilitates evaluation of PTitaniQ thermobarometry and provides additional constraints on petrologic models for origin and evolution of the rhyolites. Specifically, we present data for rhyolites from the Yellowstone center (YNP; cf. Bindeman \& Valley, 2001; Vazquez et al., 2009; Girard \& Stix, 2010) and rhyolitic lavas and domes from the small and relatively young Magic Reservoir eruptive center (MREC; Leeman, 1982; Honjo \& Leeman, 1987) in the central SRP. Additional samples of early voluminous rhyolites from the latter region (cf. Bonnichsen et al., 2008) have been studied to lesser extent and are not included in this article.

As part of this study, we also analyzed one late Precambrian rhyolite (CMB-Allph10; CMB for short) from the Portage Lake Volcanics of the Keweenawan province in northern Michigan. This sample was included because it contains large (ca. $2 \mathrm{~mm}$ ) quartz phenocrysts that previously had been found to exhibit extreme zonation in CL intensity and $\mathrm{Ti}$ content (Student et al., 2006). Finally, polished mounts of synthetic quartz from several Ti-doped 
Table 1. Sample Information and Temperature Constraints.

Sample Unit $\quad$ Description $\quad$ T constraints

\section{Geologic Samples}

Yellowstone volcanic center (YNP)

(Bindeman \& Valley, 2001; Vazquez et al., 2009)

YL-96-19 Gibbon Hill dome

YL-96-20

Middle Biscuit Basin flow

L81-25

Rhy. of Magic Reservoir (Tmr)

WBQ

Rhy. of Wedge Butte (Tyd)

L80-37

Rhy. of Dinosaur Ridge (Tyd)

L80-34

Rhy. of Rattlesnake Butte (Tyd)
Young $(\sim 0.15 \mathrm{Ma})$ extracaldera extrusive dome

Early $(0.54 \mathrm{Ma})$ post-caldera lava after eruption of Lava Creek Tuff (0.64 Ma)

Earliest ( $\sim 5 \mathrm{Ma})$ lava filling caldera-like depression

Earliest ( $\sim 5 \mathrm{Ma})$ lava filling caldera-like depression

Later ( $\sim 3 \mathrm{Ma})$ eruption

Later (3.3 Ma) eruption

Young (2.9 Ma) eruption
$811 \mathrm{Zr}$-sat $841 \mathrm{Zr}^{\prime}$-sat 864 MELTS $^{\text {a }}$

$818 \mathrm{Zr}$-sat $853 \mathrm{Zr}^{\prime}$-sat 905 Mt-Ilm 851 MELTS

$899 \mathrm{Zr}$-sat $1082 \mathrm{Zr}^{\prime}$-sat 1020 2-Px 1015 2-Fsp 953 MELTS

$889 \mathrm{Zr}$-sat $1078 \mathrm{Zr}^{\prime}$-sat $10202-\mathrm{Px}$ 1036 2-Fsp 945 MELTS

$802 \mathrm{Zr}$-sat $834 \mathrm{Zr}^{\prime}$-sat 875 MELTS n.a. ${ }^{\text {b }}$ $787 \mathrm{Zr}$-sat $818 \mathrm{Zr}^{\prime}$-sat 899 MELTS

Keweenawan rhyolite (Student et al., 2006, 2007)

CMB-Allph-10

Portage Lake Volcanics

Rhyolite cobbles in conglomerate

873 MELTS

Synthetic quartz samples

(Thomas et al., 2010)

QTiP-11

Experimental run product

Experimental run product

Experimental run product

Experimental run product

$\begin{array}{ll}\text { Quartz } & 875^{\circ} \mathrm{C} \\ \text { average } \mathrm{Ti}=96 \mathrm{ppm} & 15 \mathrm{kbar} \\ \text { Quartz } & 940^{\circ} \mathrm{C} \\ \text { average } \mathrm{Ti}=167 \mathrm{ppm} & 15 \mathrm{kbar} \\ \text { Quartz } & 700^{\circ} \mathrm{C} \\ \text { average } \mathrm{Ti}=18 \mathrm{ppm} & 15 \mathrm{kbar} \\ \text { Quartz } & 900^{\circ} \mathrm{C} \\ \text { average } \mathrm{Ti}=307 \mathrm{ppm} & 10 \mathrm{kbar}\end{array}$

${ }^{a}$ MELTS liquidus T calculated assuming $3 \mathrm{kbar}$ pressure and $3 \% \mathrm{H}_{2} \mathrm{O}$. Zr-sat and $\mathrm{Zr}^{\prime}$-sat are $\mathrm{Zr}$ saturation Ts as originally defined by Watson and Harrison (1983) and revised by Perkins and Nash (2002), respectively, based on Zr content in each sample; all samples contain trace zircon. Mineral thermometry is based on compositions of coexisting magnetite-ilmenite (Mt-Ilm), ortho- and clinopyroxene (2 Px), or plagioclase and K-feldspar (2 Fsp) pairs (cf. Honjo et al., 1992; other references in text).

${ }^{\mathrm{b}}$ n.a. $=$ not applicable.

experiments of Thomas et al. (2010) were included to allow comparison of their EMPA Ti data with our LA-ICPMS analyses of the same samples.

For most natural samples, concentrates of quartz were prepared by standard heavy liquid and magnetic separation methods, and representative grains were mounted in epoxy and studied in polished section. This approach was used in most cases so as to efficiently survey a moderate number of grains, as the number (or surface area) of exposed grains in a given thin section of the rocks was limited $(<5 \%)$ in many cases. It should be noted that many grains are fractured remnants of larger phenocrysts, but original rims can be recognized based on crystal morphology. To provide more precise spatial context and to evaluate intragrain 
compositional zoning, a few samples were studied in thin section.

\section{Analytical Methods}

\section{General Approach}

Preliminary CL maps were made of representative quartz grains using a low-resolution CL luminoscope (Smithsonian Institution, Washington, D.C., USA) to evaluate apparent mineral zoning and to guide selection of analytical points in an initial round of analyses by LA-ICPMS (see below). Selected samples were subsequently repolished at CSIRO (Clayton, VIC, Australia) to remove surface damage from both the laser and electron flood gun, and quantitative CL spectra were acquired for selected analyzed grains. Because of surface damage imparted by the laser, spectral data were necessarily integrated for areas adjacent to the original analysis spots. To provide more direct comparison of spectral and composition data, another round of LA-ICPMS analyses was made on freshly polished regions for which high-resolution CL spectroscopic imagery was available. The next sections describe in more detail the respective analytical approaches.

\section{LA-ICPMS Studies}

LA-ICPMS analyses were done at Rice University using a $213 \mathrm{~nm}$ New Wave laser ablation system coupled to a ThermoFinnigan Element 2 magnetic sector inductively coupled plasma mass spectrometer. The laser typically was operated at $40-55 \mu \mathrm{m}$ spot size with a $10 \mathrm{~Hz}$ pulse rate at a fluence of $10 \mathrm{~J} / \mathrm{cm}^{2}$. Attempts to use smaller spots (down to $25 \mu \mathrm{m}$ ) near grain rims were generally unsatisfactory owing to sample decrepitation during laser heating. Vaporized material was transported from the ablation cell using a 1.3 $\mathrm{L} / \mathrm{min}$ flow of $\mathrm{He}$, then introduced into the torch with the aid of $0.9 \mathrm{~L} / \mathrm{min}$ of Ar sample gas. Analyses were done in medium mass resolution mode $(m / \Delta m-3,000)$ to resolve molecular interferences. The following masses were measured: ${ }^{23} \mathrm{Na},{ }^{25} \mathrm{Mg},{ }^{27} \mathrm{Al},{ }^{30} \mathrm{Si},{ }^{31} \mathrm{P},{ }^{39} \mathrm{~K},{ }^{43} \mathrm{Ca},{ }^{45} \mathrm{Sc},{ }^{49} \mathrm{Ti},{ }^{51} \mathrm{~V}$, ${ }^{52} \mathrm{Cr},{ }^{55} \mathrm{Mn},{ }^{57} \mathrm{Fe},{ }^{\mathrm{c}} \mathrm{Zn},{ }^{69} \mathrm{Ga},{ }^{89} \mathrm{Y},{ }^{91} \mathrm{Zr}$, and the ${ }^{40} \mathrm{Ar}{ }^{40} \mathrm{Ar}$ dimer; some runs also included ${ }^{11} \mathrm{~B},{ }^{7} \mathrm{Li},{ }^{63} \mathrm{Cu}$, and ${ }^{64} \mathrm{Zn}$. Because interferences are negligible for ${ }^{49} \mathrm{Ti}$, all reported $\mathrm{Ti}$ concentrations are based on this isotope. For each mass, we analyzed a $120 \%$ mass window $\left(180 \%\right.$ for $\left.{ }^{40} \mathrm{Ar}{ }^{40} \mathrm{Ar}\right)$ with eight samples per $100 \%$ peak and a sample dwell time of $0.01 \mathrm{~s}$. This large mass window was necessary for peak centering, after which only an $80 \%$ mass window was integrated for quantitative evaluation. Mass scans were operated in EScan mode ( $0.03 \mathrm{~s}$ for each consecutive peak jump), but several large jumps in the magnetic field were necessary (0.3 s of magnetic settling time). One sweep across the entire mass range (from $\mathrm{Na}$ to $\mathrm{Zr}$ ) required $3.0 \mathrm{~s}$. A gas background of $\sim 10$ scans was first taken, followed by $\sim 40$ scans during actual ablation. Total ablation time for a measurement was on the order of 2 min during which time the laser excavated about $100 \mu \mathrm{m}$ of material. Long-term drift of the mass calibration was corrected during each analysis by locking the calibration to the ${ }^{40} \mathrm{Ar}^{40} \mathrm{Ar}$ dimer. Small mass offsets to the mass calibration were assigned before each day's measurements. Sensitivity in medium mass resolution was $\sim 2,000 \mathrm{cps} / \mathrm{ppm}$ for the above ablation and ICPMS conditions.

Converting signal intensities to concentrations was done by first subtracting the gas background from the ablation signal. The background-corrected signals were then normalized to an internal standard, which was chosen to be ${ }^{30} \mathrm{Si}$ $\left(\mathrm{SiO}_{2}\right.$ assumed $=100 \%$ for quartz $)$ following Longerich et al. (1996). The background-corrected, Si-normalized signal intensities of external standards were plotted against Si-normalized concentrations using GEOREM preferred values for concentrations (cf. Table 2), and from this a multistandard calibration curve regressed through the origin was established. This calibration curve was then used to convert the signal intensities of unknowns to concentrations.

Time-resolved analyses (Fig. 1) were monitored for anomalous concentrations of other elements to identify potential complications due to ablation of melt/fluid inclusions or intergrown minerals. Individual cycles showing such anomalies were excluded during data reduction. Many natural quartz grains contain significant $\mathrm{Li}(\sim 15-40 \mathrm{ppm})$ and $\mathrm{B}(\sim 1-5 \mathrm{ppm})$, and small amounts of $\mathrm{Na}$ (for nearly all samples, $<40 \mathrm{ppm}), \mathrm{Al}(<200 \mathrm{ppm})$, and $\mathrm{Fe}(<100 \mathrm{ppm})$; most other elements monitored were usually below their detection limit (defined as three times the background counts). None of these elements show any significant correlation with Ti content.

Data for this article were collected in several sessions in 2007-2009. Results of replicate standard analyses for the most recent session are presented in Table 2. Intraday precision (relative standard deviation, or RSD) for multiple analyses was on the order of $6 \%$ or better for all calibration standards. ATHO-G $(\mathrm{RSD}=3 \%)$ and NIST-612 $(\mathrm{RSD}=$ $12 \%)$, which contains only $44 \mathrm{ppm} \mathrm{Ti}$, were analyzed as independent checks on accuracy. Data for most standards agree with preferred values (cf. GEOREM website) within their estimated uncertainties, including standard averages over five earlier sessions. However, average $\mathrm{Ti}$ in the $\mathrm{Na}$ tional Institute of Standards and Technology (NIST) standards and ATHO-G is skewed above the preferred values by $11-23 \%$ (average discrepancy $=15 \%$ ). Because these Si-rich standards have matrix compositions closest to quartz, a correction of $15 \%$ was applied to all quartz samples to compensate for matrix effects (cf. Morrison et al., 1995). Based on these results as well as replicate analyses of natural samples, we conservatively estimate external reproducibility of $\mathrm{Ti}$ concentration to be within $\pm 10 \%$ for samples $>100 \mathrm{ppm}$, and within $\pm 20 \%$ for samples $<100 \mathrm{ppm}$. Table 3 presents representative data for the samples used in this study.

\section{Spectral Studies}

Prior to analysis, each sample was highly polished using $0.25 \mu \mathrm{m}$ diamond paste followed by $20 \mathrm{~nm}$ colloidal silica solution dispersed in water to minimize surface damage 
(a) Time-series ICPMS analysis of NIST SRM-612
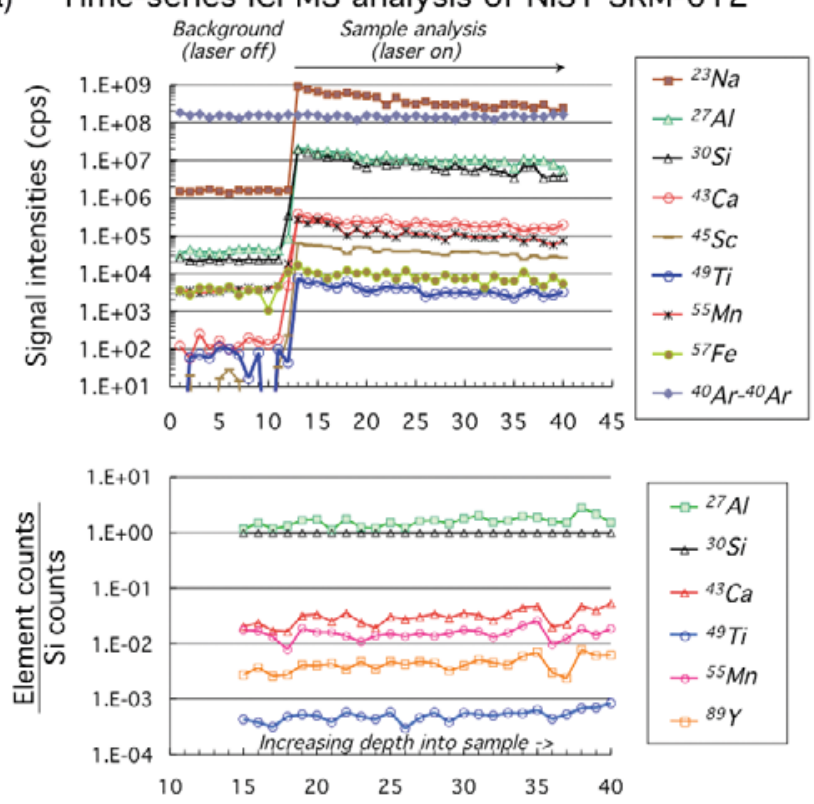

(c)
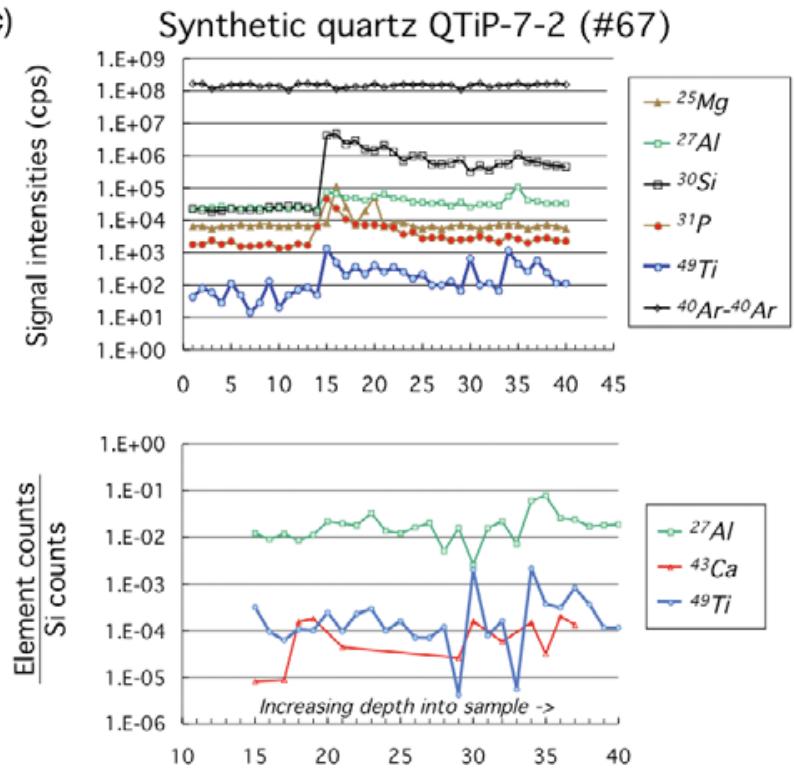

that can lead to CL active centers (Remond et al., 2000). This preparation is deemed critical to obtaining high quality CL data. Hyperspectral data $(200-990 \mathrm{~nm})$ were collected on selected grains by stage scanning in $2-\mu \mathrm{m}$ steps $(2 \times 2 \mu \mathrm{m}$ pixel resolution) on a JEOL $8500 \mathrm{~F}$ (JEOL Ltd., Tokyo, Japan) electron microprobe (EMPA) at $20 \mathrm{kV}$ accelerating voltage and $40 \mathrm{nA}$ beam current. This instrument is equipped with an integrated grating CL spectrometer and charge-coupled device detector (MacRae et al., 2009). A critical advantage of this system is the short data acquisition time (dwell time of $30 \mathrm{~ms}$ ) required per pixel, as this minimizes effects of surface damage and time-dependent CL intensity. For each pixel, wavelength dispersive X-ray data were simultaneously collected for $\mathrm{Ti}, \mathrm{Al}, \mathrm{Fe}, \mathrm{Mg}$, and $\mathrm{Si}$ in addition to a full energy dispersive X-ray spectrum to identify any inclusions or other anomalies encountered. (b)
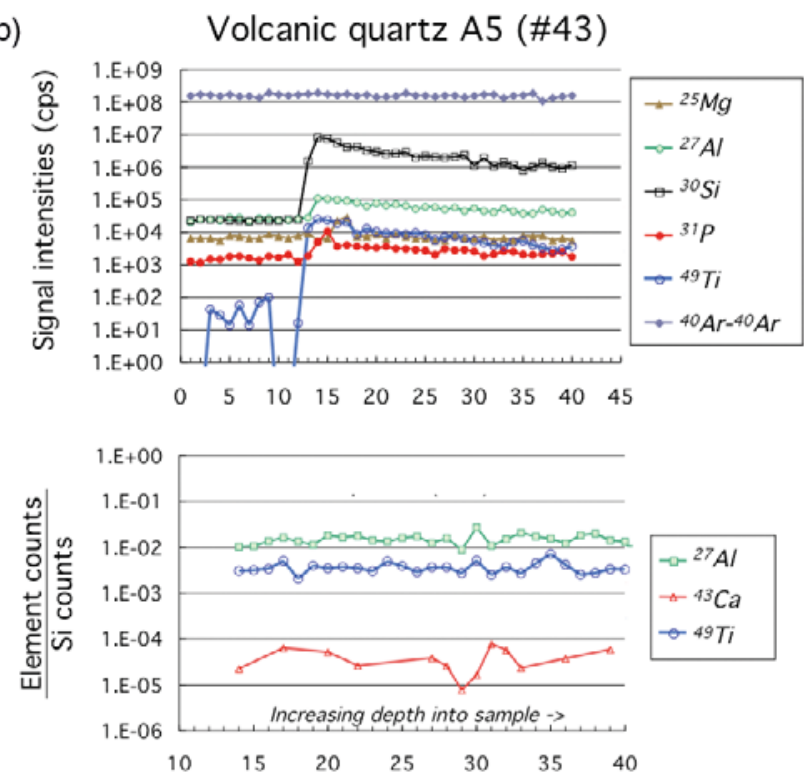

Figure 1. LA-ICPMS data acquisition. (a) Example of ICPMS intensity profiles (log-scale) for selected elements monitored during analysis of standard SRM-612. The time decay reflects a decreasing volume of entrained sample vapor as the laser burrows deeper. After background correction, variations in sample signal are compensated by normalizing element intensities to that for ${ }^{30} \mathrm{Si}$. As seen in the lower panel, the normalized signals are relatively constant. (b) Similar diagram for a natural volcanic quartz sample (A5; rhyolite of Magic Reservoir) from the Snake River Plain, showing data for selected elements. This is a satisfactory analysis, with relatively constant Si-normalized element ratios for $\mathrm{Ti}$ and other elements that are above background levels. (c) Similar diagram for a synthetic quartz sample (QTiP-7). In this case, Si-normalized ratios for $\mathrm{Ti}$ are notably erratic after the first 25 analysis cycles. This is attributed to sample heterogeneity as also reflected by significant zoning of CL intensity for this sample.

Acquisition of a typical CL map area of $1700 \times 1400$ pixels $(3.4 \times 2.8 \mathrm{~mm})$ required about $23 \mathrm{~h}$. Complete spectral data were acquired for each pixel, allowing analysis and construction of spatial maps of all measured parameters. It should be noted that, over the period of this study, changes in the instrument configuration and evolution of data acquisition methods introduced some variation in exact peak positions and intensities. Differences in surface condition and artifacts from prior electron beam or laser damage could also contribute to differences in CL spectral response over the course of this study.

In detail, the CL spectra were deconvolved in energy space using Chimage software (Harrowfield et al., 1993) to fit a series of Gaussians to the major and minor peaks within the CL spectra. Three principal contributions (peaks near $1.93,2.19$, and $2.72 \mathrm{eV}$; equivalent wavelengths near 
Table 2. LA-ICPMS Analyses of Standard Reference Glasses (Rice University).

\begin{tabular}{lcccccc}
\hline Standard & BHVO & BCR & BIR & NIST610 & NIST612 & ATHO-G \\
\hline Average Nov. 2009 & 16,358 & 14,387 & 5,297 & 501 & 49 & 1,888 \\
SD & 910 & 881 & 172 & 22 & 6 & 57 \\
RSD & $5.6 \%$ & $6.1 \%$ & $3.2 \%$ & $4.4 \%$ & $11.8 \%$ & $3.0 \%$ \\
N & 9 & 7 & 5 & 6 & 4 & 4 \\
PV-Ti ppm & 16,300 & 14,100 & 5,400 & 452 & 44 & 1,529 \\
\% Avg:PV & $0.4 \%$ & $2.0 \%$ & $-1.9 \%$ & $10.9 \%$ & $10.5 \%$ & $23.5 \%$ \\
Previous sessions & & & & & \\
Average of session means $(N=5)$ & 16,475 & 14,129 & 5,418 & n.d. ${ }^{\text {a }}$ & 45 & 1,791 \\
SD & 414 & 656 & 140 & n.d. & 2 & 163 \\
RSD & $2.6 \%$ & $5.0 \%$ & $2.5 \%$ & n.d. & 4.5 & $9.1 \%$ \\
\hline
\end{tabular}

Note: Data shown for November 2009 analyses correspond to majority of data in Table 2. Calibration curve for [Ti ppm/Si ppm] versus [Ti-int/Si-int] is based on first four standards assuming preferred values (PV) for Ti and Si taken from the GEOREM website. Average Ti concentration and standard deviation are based on $N$ individual analyses for each standard. NIST-612 and ATHO-G were not used for calibration but analyzed as an independent checks on accuracy. Precision is better than ca. $6 \%$ for all standards except the low-Ti NIST-612 (12\%). Accuracy (\% Avg:PV) is better than $2 \%$ for high-Ti standards, but a bias of $\sim 11 \%$ is apparent for the NIST standards and $\sim 23 \%$ for ATHO-G, all of which have systematically higher Si and distinctive matrix composition. Reported data in Table 2 are based on a 15\% reduction of measured Ti content for all quartz samples as these more closely match matrix compositions of the high-Si standards. Standards data from previous sessions are in close agreement (see averages of earlier session means).

${ }^{a}$ n.d. $=$ not determined.

642,566 , and $456 \mathrm{~nm}$ ) appear to be satisfactorily resolved in most samples. The first two peaks likely correspond to nonbridging oxygen hole (NBOH) and intrinsic quartz contributions (cf. Luff \& Townsend, 1990; Stevens-Kalceff \& Phillips, 1995; Stevens-Kalceff, 2009; Vasyukova et al., 2013); however, intensity of the third spectral component is strongly correlated with $\mathrm{Ti}^{4+}$ content, particularly for specific samples (see details below). Figure 2 shows representative CL spectra for three areas in a zoned quartz crystal. The spectra differ primarily in the intensity of the ca. $2.7 \mathrm{eV}$ peak, with nearly twofold difference in intensity for areas containing 28 and $57 \mathrm{ppm} \mathrm{Ti}$. The other prominent peak (ca. $1.9 \mathrm{eV}$ ) has nearly uniform intensity for all three areas sampled but shows diminishing relative prominence as $\mathrm{Ti}$ content increases. Figure 3 shows a map of $2.7 \mathrm{eV}$ CL intensity for a representative quartz grain, illustrating complex patterns of internal zoning; a false color scale is used to enhance the variation in CL intensity, and a line profile is presented to highlight the main topological features. Deconvolved energy peaks are illustrated for distinctively high and low CL areas. Relative intensities for these energy peaks vary considerably within many samples, and to an even greater extent between samples. As Ti content decreases, the lower energy peaks become increasingly prominent (Fig. 2). For this reason, total CL intensity (or "grayscale" intensity as used by Landtwing \& Pettke, 2005), for example, cannot be expected to vary linearly in detail with content of Ti or other exciton elements.

Each of the resolved energy contributions can be mapped separately to illustrate the last point. This is illustrated in Figure 4, which provides examples of the map distribution of intensity for the $1.95,2.32$, and $2.7 \mathrm{eV}$ resolved components for a representative sample, the latter of which directly reflects the distribution of Ti. In particular, it can be seen that intensities and gradients in the 1.95 and $2.32 \mathrm{eV}$ maps are quite low and reflect relatively uniform CL contributions inherent to the quartz structure. However, all images clearly reflect the distinctive overgrowth of Ti-rich quartz on an earlier formed lower-Ti core. The $2.7 \mathrm{eV}$ map provides maximum detail, indicating a somewhat oscillatory growth pattern for the core area, and apparent truncation of the grain before final overgrowth of the rim. Implications of such growth patterns will be discussed later.

\section{Other Analyses}

We utilize EMPA data obtained at Rennselaer Polytechnic Institute (RPI) using a Cameca SX-100 instrument (Cameca, Madison, WI, USA) and methods as discussed by Thomas et al. (2010) and references therein. A four-spectrometer data acquisition system is used to measure trace Ti contents, and calibration is based on analysis of a rutile $\left(\mathrm{TiO}_{2}\right)$ standard. Approaching the effective detection limit of ca. $15 \mathrm{ppm}$, precision is approximately $\pm 50 \%$. At concentrations above $100 \mathrm{ppm}$, precision is better than $\pm 10 \%$. However, sample heterogeneity can be a limiting factor on precision (cf. Table 4).

We also refer to LA-ICPMS data obtained at Virginia Polytechnic Institute (VPI) for quartz and melt inclusions. There, an Agilent 7500ce ICPMS (Allied Electronics, Inc., Fort Worth, TX, USA) is coupled with a GeoLas $193 \mathrm{~nm}$ laser system (Coherent Inc., Santa Clara, CA, USA), and calibration is based on analysis of the NIST standards used at Rice University. Overall precision and accuracy are comparable between the two labs.

\section{Results}

Analytical results are presented in Table 3. Because we are concerned with the potential correlation of Ti content with 
Table 3. Ti Contents and Spectral Intensities for Quartz Samples.

\begin{tabular}{|c|c|c|c|c|c|}
\hline Description & Sample ID & $\begin{array}{l}\text { Ti ppm } \\
\text { ICPMS }\end{array}$ & $\begin{array}{l}\text { Ti ppm } \\
\text { EMPA }\end{array}$ & $\begin{array}{c}\text { PTitaniQ } \\
T\left({ }^{\circ} \mathrm{C}\right) \\
\text { EMPA }\end{array}$ & $\begin{array}{c}\text { CL } 2.71 \mathrm{eV} \\
(457 \mathrm{~nm}) \\
\mathrm{CPS}\end{array}$ \\
\hline \multicolumn{6}{|c|}{ Synthetic Quartz } \\
\hline \multirow[t]{6}{*}{$875^{\circ} \mathrm{C}, 1.5 \mathrm{GPa}$} & QTiP-11-bottom & n.d. ${ }^{a}$ & 67 & 822 & 25.13 \\
\hline & QTiP-11-bottom & n.d. & 67 & 822 & 26.39 \\
\hline & QTiP-11-bottom & n.d. & 115 & 887 & 26.87 \\
\hline & QTiP-11-bottom & n.d. & 115 & 887 & 27.39 \\
\hline & QTiP-11-bottom & 99 & 67 & 822 & 21.99 \\
\hline & QTiP-11-bottom & n.d. & 67 & 822 & 21.37 \\
\hline \multirow[t]{3}{*}{$940^{\circ} \mathrm{C}, 1.5 \mathrm{GPa}$} & QTiP-10-mid & 212 & 170 & 940 & 59.51 \\
\hline & QTiP-10-mid & 195 & 157 & 929 & 56.70 \\
\hline & QTiP-10-mid & 235 & 157 & 929 & 56.64 \\
\hline \multirow[t]{2}{*}{$700^{\circ} \mathrm{C}, 1.5 \mathrm{GPa}$} & QTiP-7-top & 37 & 28 & 730 & 9.78 \\
\hline & QTiP-7-top & 38 & 20 & 699 & 9.61 \\
\hline \multirow[t]{12}{*}{$900^{\circ} \mathrm{C}, 1.0 \mathrm{GPa}$} & QTiP-19-bot & 423 & n.d. & n.d. & 86.66 \\
\hline & QTiP-19-bot & 386 & 300 & 895 & 83.28 \\
\hline & QTiP-19-bot & 324 & 300 & 895 & 77.39 \\
\hline & QTiP-19-mid & 359 & n.d. & n.d. & 92.02 \\
\hline & QTiP-19-mid & 465 & 320 & 905 & 91.11 \\
\hline & QTiP-19-mid & 386 & 310 & 900 & 86.98 \\
\hline & QTiP-19-top & 454 & n.d. & n.d. & 74.94 \\
\hline & QTiP-19-top & 450 & n.d. & n.d. & 82.60 \\
\hline & QTiP-19-top & 334 & 308 & 899 & 80.49 \\
\hline & QTiP-19-top & 351 & 308 & 899 & 79.15 \\
\hline & QTiP-19-top & 371 & n.d. & n.d. & n.d. \\
\hline & QTiP-19-top & 354 & n.d. & n.d. & n.d. \\
\hline Description & Sample ID & $\begin{array}{c}\text { Ti-ICPMS } \\
(\mathrm{ppm})\end{array}$ & $\begin{array}{l}\text { P-assumed } \\
\text { (kbar) }\end{array}$ & $\begin{array}{l}\text { T-calc } \\
\left({ }^{\circ} \mathrm{C}\right)\end{array}$ & $\begin{array}{c}\text { CL } 2.71 \mathrm{eV} \\
\text { CPS }\end{array}$ \\
\hline \multicolumn{6}{|c|}{ Natural Quartz Phenocrysts_CL Mapping before LA-ICPMS Analysis (Nov. 2009) } \\
\hline L81-20 (Tmr) & A5-1 & 443 & 4 & 1,073 & 96.42 \\
\hline$a_{\mathrm{TiO}_{2}}=0.25$ & A5-1 & 315 & 4 & 1,002 & 90.68 \\
\hline L81-20 (Tmr) & A5-2 & 155 & 4 & 875 & 62.18 \\
\hline \multirow[t]{2}{*}{$a_{\mathrm{TiO}_{2}}=0.25$} & A5-2 & 166 & 4 & 886 & 62.92 \\
\hline & A5-2 & 416 & 4 & 1,059 & 112.42 \\
\hline L81-20 (Tmr) & A5-3 & 353 & 4 & 980 & 82.84 \\
\hline$a_{\mathrm{TiO}_{2}}=0.25$ & A5-3 & 342 & 4 & 974 & 70.94 \\
\hline YL-19 & A6-1 & 32 & 6 & 748 & 19.74 \\
\hline Gibbon Hill & A6-1 & 32 & 6 & 800 & 20.45 \\
\hline \multirow[t]{2}{*}{$a_{\mathrm{TiO}_{2}}=0.10$} & A6-1 & 49 & 6 & 803 & 21.04 \\
\hline & A6-1 & 33 & 6 & 752 & 19.83 \\
\hline L80-34 (Tyd) & A1-1 & 45 & 4 & 740 & 29.65 \\
\hline \multirow[t]{3}{*}{$a_{\mathrm{TiO}_{2}}=0.10$} & Al-1 & 46 & 4 & 742 & 29.45 \\
\hline & A1-1 & 106 & 4 & 860 & 28.78 \\
\hline & A1-1 & 138 & 4 & 903 & 69.66 \\
\hline L80-34 (Tyd) & $A 1-2 b$ & 161 & 4 & 930 & 35.88 \\
\hline \multirow{3}{*}{$a_{\mathrm{TiO}_{2}}=0.10$} & $A 1-2 b$ & 48 & 4 & 748 & 16.47 \\
\hline & A1-2a & 40 & 4 & 725 & 15.47 \\
\hline & Al-2a & 192 & 4 & 962 & 35.62 \\
\hline L81-25 (Tmr) & A2-4 & 324 & 4 & 964 & 98.66 \\
\hline \multirow[t]{2}{*}{$a_{\mathrm{TiO}_{2}}=0.25$} & A2-4 & 231 & 4 & 904 & 70.55 \\
\hline & A2-4 & 249 & 4 & 917 & 80.57 \\
\hline L81-25 (Tmr) & $\mathrm{A} 2-3$ & 301 & 4 & 950 & 65.44 \\
\hline \multirow{3}{*}{$a_{\mathrm{TiO}_{2}}=0.25$} & A2-3 & 184 & 4 & 866 & 45.39 \\
\hline & $\mathrm{A} 2-2$ & 399 & 4 & 1,004 & 62.05 \\
\hline & A2-1 & 339 & 4 & 972 & 58.89 \\
\hline
\end{tabular}


Table 3. Continued

\begin{tabular}{|c|c|c|c|c|c|}
\hline Description & Sample ID & $\begin{array}{c}\text { Ti-ICPMS } \\
(\mathrm{ppm})\end{array}$ & $\begin{array}{c}\text { P-assumed } \\
\text { (kbar) }\end{array}$ & $\begin{array}{c}\text { T-calc } \\
\left({ }^{\circ} \mathrm{C}\right)\end{array}$ & $\begin{array}{c}\text { CL } 2.71 \mathrm{eV} \\
\text { CPS }\end{array}$ \\
\hline \multicolumn{6}{|c|}{ Natural Quartz Phenocrysts_CL Mapping before LA-ICPMS Analysis (Nov. 2009) (continued) } \\
\hline L80-37 (Tyd) & A4-1 & 401 & 4 & 1,051 & 120.57 \\
\hline \multirow{3}{*}{$a_{\mathrm{TiO}_{2}}=0.15$} & A4-1 & 436 & 4 & 1,070 & 125.04 \\
\hline & A4-1 & 436 & 4 & 1,070 & 123.17 \\
\hline & A4-1 & 257 & 4 & 962 & 52.50 \\
\hline L80-37 (Tyd) & A4-2 & 250 & 4 & 957 & {$[109.58]^{\mathrm{b}}$} \\
\hline$a_{\mathrm{TiO}_{2}}=0.15$ & A4-2 & 298 & 4 & 991 & {$[108.74]^{\mathrm{b}}$} \\
\hline \multicolumn{6}{|c|}{ Natural Quartz Phenocrysts_CL Mapping after LA-ICPMS Analysis (2008) } \\
\hline L80-37 (Tyd) & A4-2 & 379 & 4 & 1,039 & 94.2 \\
\hline \multirow{3}{*}{$a_{\mathrm{TiO}_{2}}=0.15$} & A4-2 & 361 & 4 & 1,029 & 85.2 \\
\hline & A4-2 & 179 & 4 & 898 & 38.9 \\
\hline & A4-2 & 232 & 4 & 944 & 62.7 \\
\hline L81-20 (Tmr) & A5-1 & 305 & 4 & 953 & 93.5 \\
\hline \multirow{2}{*}{$a_{\mathrm{TiO}_{2}}=0.25$} & A5-1 & 121 & 4 & 803 & 50.3 \\
\hline & A5-1 & 246 & 4 & 914 & 60.7 \\
\hline YL-20 & A7 & 243 & 4 & 1,007 & 76.8 \\
\hline Biscuit Basin & A7 & 258 & 4 & 963 & 81.2 \\
\hline \multirow[t]{5}{*}{$a_{\mathrm{TiO}_{2}}=0.20$} & A7 & 259 & 4 & 964 & 89.7 \\
\hline & A7 & 271 & 4 & 972 & 86.7 \\
\hline & A7 & 279 & 4 & 978 & 93.9 \\
\hline & A7 & 274 & 4 & 974 & 95.8 \\
\hline & A7 & 351 & 4 & 1,023 & 113.2 \\
\hline YL-19 & A6-2 & 57 & 6 & 884 & 25.5 \\
\hline Gibbon Hill & A6-2 & 28 & 6 & 783 & 16.6 \\
\hline$a_{\mathrm{TiO}_{2}}=0.10$ & A6-2 & 27 & 6 & 778 & 16.5 \\
\hline \multicolumn{6}{|c|}{ CMB Quartz Traverse } \\
\hline Keweenawan & 1-interior & 40 & 3 & 699 & 21.99 \\
\hline \multirow[t]{10}{*}{$a_{\mathrm{TiO}_{2}}=0.15$} & 2 & 60 & 3 & 750 & 22.30 \\
\hline & 3 & 4 & 3 & 486 & 6.58 \\
\hline & 4 & 15 & 3 & 595 & 9.96 \\
\hline & 5 & 19 & 3 & 618 & 12.15 \\
\hline & 6 & 62 & 3 & 754 & 27.72 \\
\hline & 7 & 89 & 3 & 805 & 35.68 \\
\hline & 8 & 215 & 3 & 951 & 68.08 \\
\hline & 8 & 289 & 3 & 1,009 & 91.56 \\
\hline & 10 & 262 & 3 & 989 & 95.00 \\
\hline & 11-rim & 232 & 3 & 965 & 70.52 \\
\hline
\end{tabular}

Notes: Synthetic quartz samples are from the experiments of Thomas et al. (2010); all are nominally equilibrated with rutile which fixes $a_{\mathrm{TiO}_{2}}=1$.0. Experimental run conditions are given in column 1. PTitaniQ temperatures (column 5) for these samples are based on the EMPA Ti concentrations (column 3) and actual run pressure (column 1); they agree closely with actual experiment temperature at appropriate pressure (see text). Natural quartz samples were analyzed only by ICPMS; PTitaniQ temperatures based on these data assume nominal pressures in kbar (column 4, for these samples) and $a_{\mathrm{TiO}_{2}}$ values calculated using RMELTS (Gualda et al., 2012); pressure was based on preliminary amphibole-plagioclase barometry and calculated Ts are similar to results from independent mineral thermometry where available (see text). Spectroscopic measurements are given as intensity (cps) for the deconvolved $2.7 \mathrm{eV}$ peak corresponding to presence of $\mathrm{Ti}^{4+}$. Data were collected on freshly polished surfaces and integrated as described in the text.

${ }^{a}$ n.d. = not determined.

${ }^{\mathrm{b}}$ Data for two points (L80-37, grain A4-2) are anomalously high and are omitted from all plots and correlations. Corresponding EMPA Ti data (cf. Table 4) are interpolated from actual analyses to the areas of laser analysis so as to provide direct comparison. Note, however, that EMPA and ICPMS data do not represent the same sample volume. 

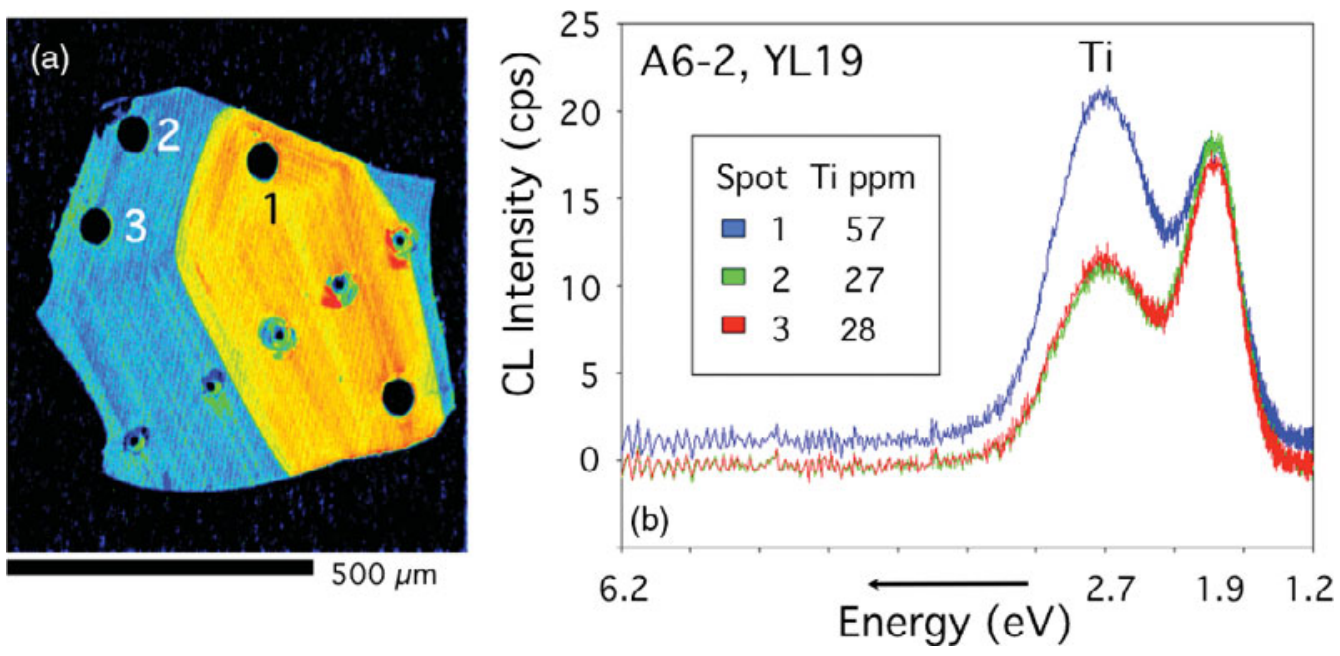

Figure 2. Relation between CL spectral intensity and variation in Ti content for representative quartz grain from sample A6 (YL-19; rhyolite of Gibbon Hill, Yellowstone). (a) Map of CL intensity (warmer colors = higher intensity), with loci of laser analyses. (b) Spectra are shown for areas adjacent to analysis spots numbered 1-3, with data averaged over zones of similar overall intensity. Spot \#1 corresponds to higher Ti $(57 \mathrm{ppm})$ than spots \#2 and \#3 (both ca. $28 \mathrm{ppm}$ ). Note that spectral peak near $1.9 \mathrm{eV}$ corresponds to intrinsic CL productivity for quartz, and its intensity is uncorrelated with Ti content. Intensity of spectral peak centered near $2.7 \mathrm{eV}$ varies closely with Ti content.
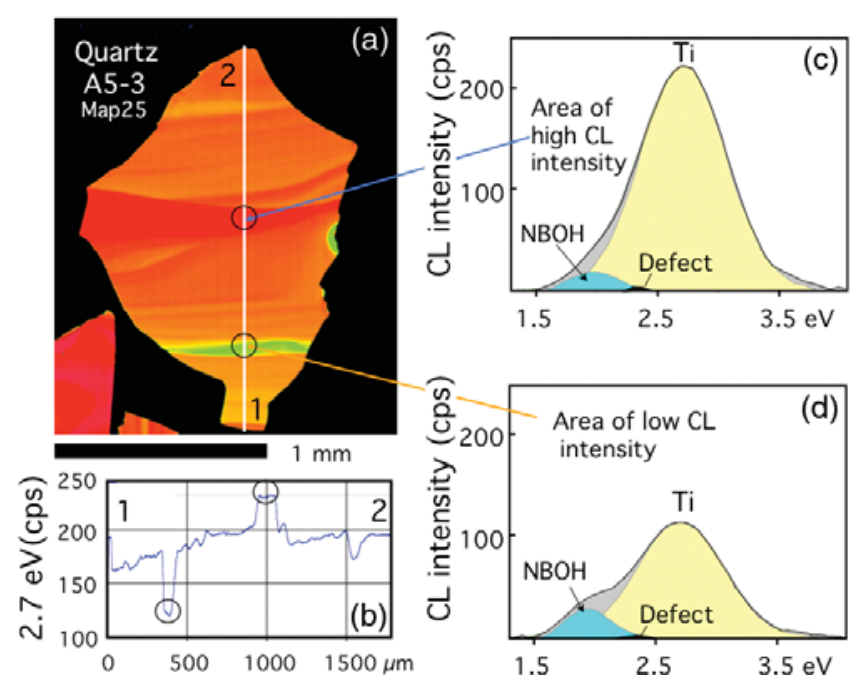

Figure 3. Example of spectral deconvolution. (a) CL map for a representative quartz grain from sample A5 (rhyolite of Magic Reservoir, Tmr), showing well-developed banding and truncations in CL intensity. (b) Line profile between points 1 and 2 (in panel a) shows variation in intensity of the deconvolved $2.7 \mathrm{eV}$ peak with position across the grain. Open circles annotate distinctive highand low-intensity points along the profile. (c, d) Deconvolved Gaussian peak contributions to the overall CL spectra are illustrated for areas of anomalously high and low CL intensity. Major peaks are associated with CL emission due to substitution of $\mathrm{Ti}^{4+}$ for $\mathrm{Si}^{4+}$ on structural sites (Ti) and the presence of $\mathrm{NBOH}$ in the crystal structure; a small peak near $2.3 \mathrm{eV}$ is associated with defect structures.

CL intensity, Table 3 shows intensities of the deconvolved $2.71 \mathrm{eV}(458 \mathrm{~nm})$ contribution for each sample investigated. Intensities are integrated for surface areas equivalent to the corresponding laser analysis spot. Also shown are the $\mathrm{Ti}$ concentrations determined by LA-ICPMS and, where available, EMPA.

Approximate temperatures are also indicated based on application of the PTitaniQ thermobarometer (Thomas et al., 2010). For synthetic quartz, which was grown in the presence of rutile, these are calculated using $a_{\mathrm{TiO}}^{\text {melt-rutile }}=1$ [i.e., activity of $\mathrm{Ti}$ in melt relative to rutile (or pure $\mathrm{TiO}_{2}$ ); subsequently designated as $a_{\mathrm{TiO}_{2}}$ for brevity], and using the known pressure of the synthesis runs; these calculations simply verify the accuracy of the PTitaniQ algorithm for examples of the calibration runs. Note that absolute deviations for all calibration data relative to $\mathrm{P}-\mathrm{T}$ values predicted by the model [Thomas et al., 2010; equation (9)] average $\pm 0.9 \mathrm{kbar}$ and $\pm 20^{\circ} \mathrm{C}$, respectively. For natural samples, $a_{\mathrm{TiO}_{2}}$ is calculated using the Rhyolite-MELTS program (RMELTS; Gualda et al., 2012), and nominal pressure values consistent with (1) experimental results of Almeev et al. (2012), (2) inferred depths of the magma reservoirs as discussed earlier (cf. Table 1), and preliminary amphiboleplagioclase barometry (cf. Anderson \& Smith, 1995) on two MREC rhyolites. For the rhyolite compositions studied (cf. Bindeman \& Valley, 2001; Leeman, unpublished data), and for average melt inclusions in Keweenawan quartz (Student et al., 2007), $a_{\mathrm{TiO}_{2}}$ values cluster near 0.15 and 0.25 . Because these values vary little as a function of pressure and increase only slightly with increasing $\mathrm{H}_{2} \mathrm{O}$ content, we conclude that the calculated range in activity largely reflects differences in magmatic $\mathrm{TiO}_{2}$ content. Values used for individual samples are indicated in Table 3. Also, for comparison, if all experiments of Thomas et al. (2010) are recalculated using the thermobarometer algorithm of Huang and Audétat (2012), pressures are underestimated by an average of $4.5 \mathrm{kbar}$ (using the experimental $\mathrm{T}$ ); conversely, temperature is overestimated by an average of $85^{\circ} \mathrm{C}$ (using the experimental $\mathrm{P}$ ). 

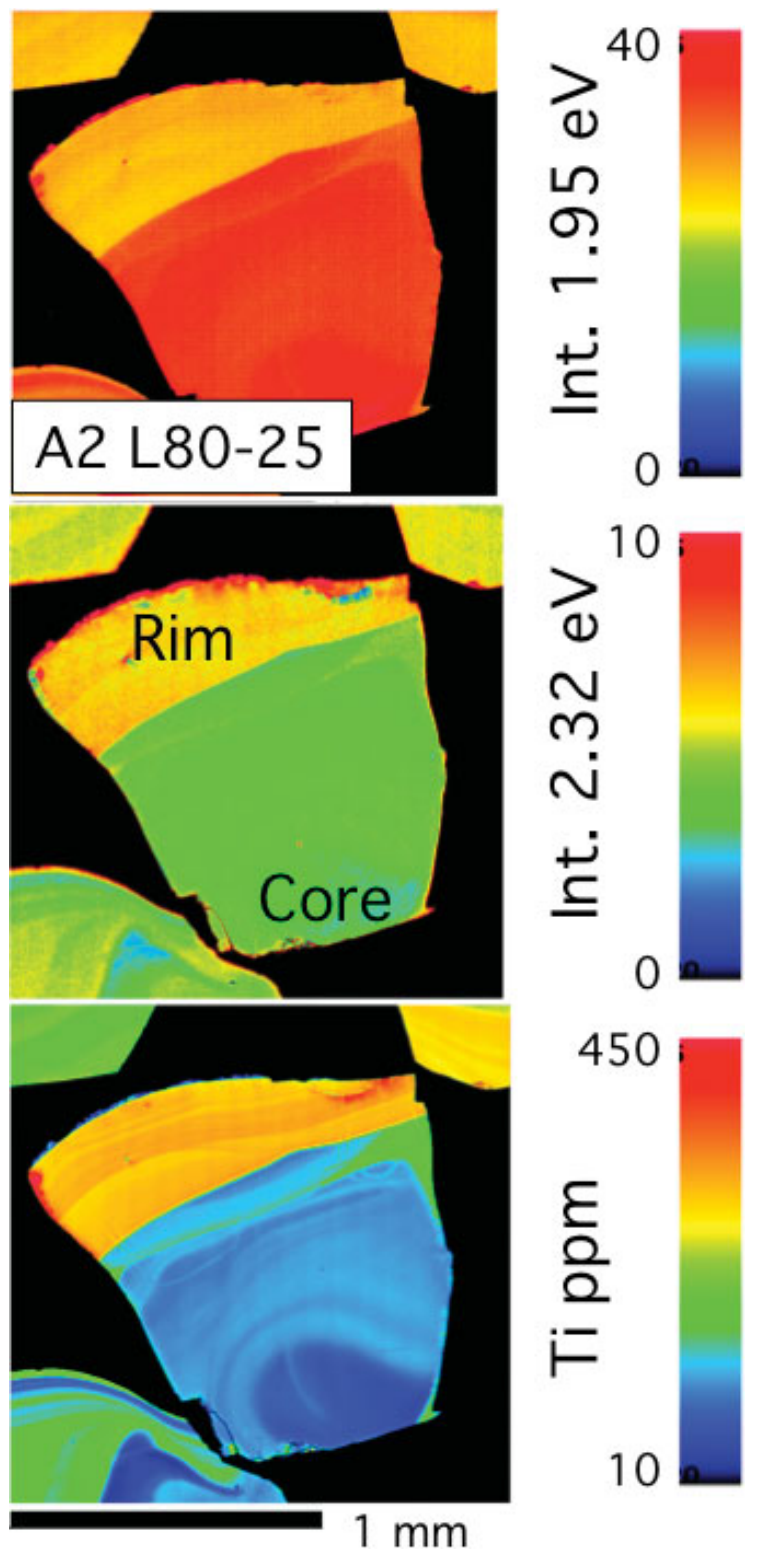

Figure 4. CL intensity maps for quartz from a high temperature rhyolite lava (sample A2; rhyolite of Magic Reservoir, Tmr). Resolved components (see text) were estimated for each pixel then used to map spatial variation in intensity for each resolved energy peak. Color scales adjacent to each image indicate the range in intensity observed as counts per second or, in the case of the $2.7 \mathrm{eV}$ peak, Ti content based on linear correlation between intensity and concentration. Note that $\mathrm{NBOH}(1.95 \mathrm{eV})$ contributions are enhanced in the crystal core where Ti content is lowest.

For convenience the PTitaniQ thermobarometer is utilized for later discussion in this article.

One principal goal of this study was to evaluate the accuracy and precision of LA-ICPMS data for Ti in quartz samples. To this end, we analyzed a number of previously characterized samples. The first is a single large quartz grain in sample CMB (Student et al., 2006) that was analyzed by both EMPA (RPI) and LA-ICPMS (VPI) to document core to rim variation in Ti. We conducted a parallel LA-ICPMS traverse that closely replicates the previous data (Fig. 5),

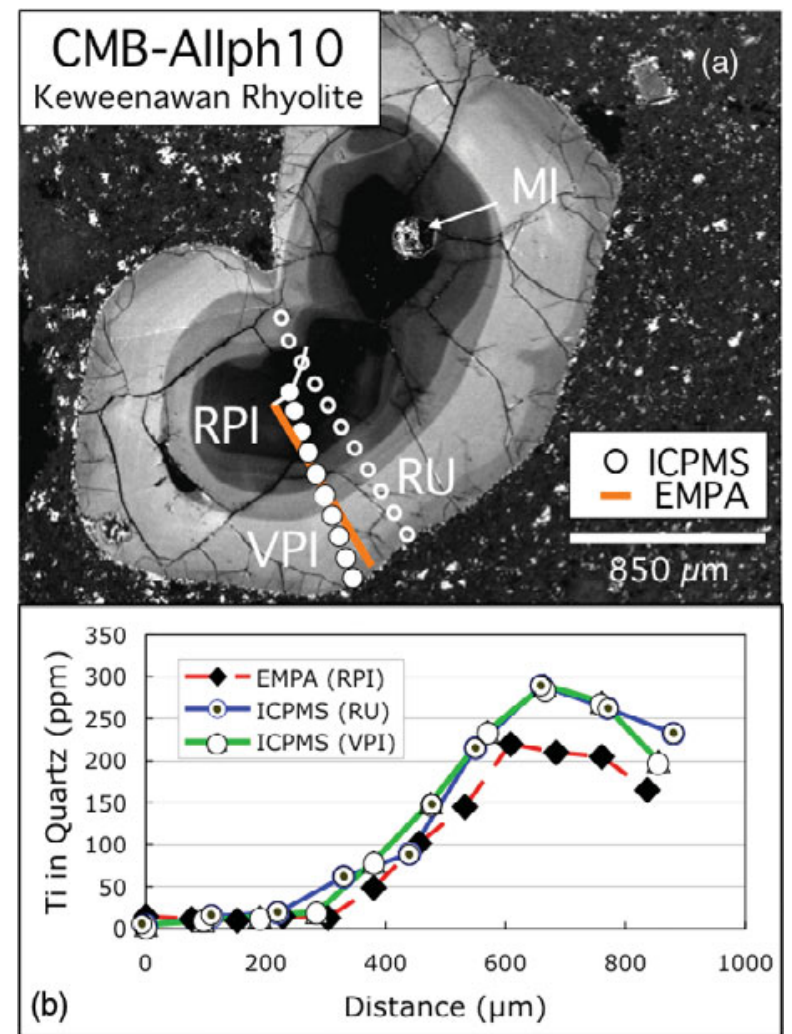

Figure 5. (a) Grayscale CL intensity map showing loci of analysis transects in a large quartz grain from sample CMB (Portage Lake Volcanics). Note presence of a now-crystallized melt inclusion (MI) in near-euhedral dark core of the large grain. (b) Superposed line profiles for $\mathrm{Ti}$ concentrations obtained by LA-ICPMS (RU, this study; VPI, Student et al., 2006) and by EMPA (RPI, Student et al., 2006). Note that all transects arbitrarily begin near core of the crystal (along white curved line) and progress outward toward the crystal rim.

with concentrations ranging from less than 5 to nearly $300 \mathrm{ppm}$ Ti. Line profiles for the two sets of LA-ICPMS data are remarkably similar, especially considering that analysis spots were necessarily offset. Both LA-ICPMS datasets are slightly elevated in Ti relative to the EMPA data, but differences are within analytical uncertainties of the two methods for the majority of analyzed areas. A second comparison can be made based on EMPA (RPI) and LA-ICPMS (Rice) analyses of quartz in selected Snake River Plain rhyolites. Results are shown (Fig. 6) for one representative example. Again, the ICPMS data appear to be slightly elevated for comparable points (especially near the crystal rim), but differences in sample volume could partly be responsible for divergence of these data. For example, one ICPMS point averaged $94 \mathrm{ppm}$, but concentrations varied significantly with depth (123-78 ppm).

Further comparison was attempted using synthetic quartz samples that were previously analyzed by EMPA at RPI (Thomas et al., 2010). As noted earlier, these samples exhibit CL zoning indicative that some grew in two distinct stages-e.g., an early "skeletal" framework (brighter CL) followed by infilling of compositionally distinctive quartz 
Table 4. EMPA Titanium Analyses for Synthetic Quartz.

\begin{tabular}{lcrrrrrrr}
\hline Sample & EMPA Average & SD & $\%$ RSD & $N$ & ICPMS Average & SD & $\%$ RSD & $N$ \\
\hline QTiP-7 & 20.5 & 7.4 & $36.1 \%$ & 10 & 32 & 8.5 & $26.5 \%$ & 2 \\
QTiP-10 & 158.5 & 16.5 & $10.4 \%$ & 10 & 214 & 20.0 & $9.3 \%$ \\
Bright CL & 165.5 & 7.9 & $4.7 \%$ & 8 & - & - & - \\
Dark CL & 135.5 & 0.7 & $0.5 \%$ & 2 & - & - & - \\
QTiP-11 & 92.9 & 27.3 & $29.4 \%$ & 10 & 99 & - & - \\
Bright CL & 118.6 & 4.3 & $3.6 \%$ & 5 & - & - & - \\
Dark CL & 67.2 & 2.3 & $3.4 \%$ & 5 & - & - & - \\
QTiP-19 & 301.3 & 24.5 & $8.1 \%$ & 15 & 388 & 48.8 & $12.6 \%$ & 12 \\
\hline
\end{tabular}

Note: EMPA data were collected using a Cameca SX-100 electron microprobe with $15 \mathrm{kV}$ accelerating potential, 200 na beam current, and $400 \mathrm{~s}$ counts on four spectrometers. Analytical procedures are discussed in Thomas et al. (2010) and references therein.

(darker CL; cf. Fig. 7a). The EMPA resolution is sufficient to obtain meaningful analyses of the two populations, albeit some heterogeneity is evident. On the other hand, considering the coarser resolution of LA-ICPMS analyses, it was impossible to ensure that a single quartz domain was sampled in any given analysis, even with a more focused laser spot (down to $25 \mu \mathrm{m}$ ). Although not conspicuous in most of the time-series analyses, intergrowths of the distinct domains were likely encountered as the laser burrowed beneath the crystal surface (e.g., as seen in Fig. 1c). Another factor to consider is that the samples were repolished following EMPA analysis, such that the surface exposed to LA-

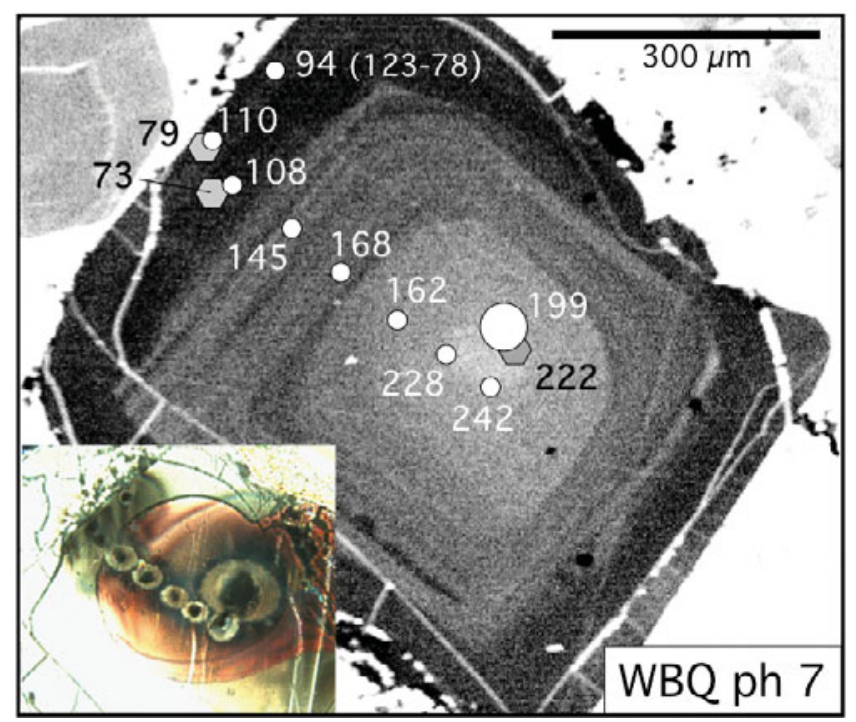

Figure 6. Volcanic quartz phenocryst (sample WBQ-7, rhyolite of Wedge Butte, Snake River Plain; Tyd) showing CL zoning and a decrease in Ti content from core to rim. EMPA (black numbers, hexagon spots) and ICPMS (white numbers, white circles) show similar concentration gradients, albeit the latter clearly sample a larger volume. In one case, ICPMS data record significant variability in Ti content (78 to $123 \mathrm{ppm}$ ), increasing with depth beneath the surface. Inset shows photomicrograph of sample surface "battleground" following laser attack, with pit diameters of $40 \mu \mathrm{m}$ (for most) to $160 \mu \mathrm{m}$ (1). There is a nearly twofold decrease in Ti from core (ca. $240 \mathrm{ppm}$ ) to rim (ca. $100 \mathrm{ppm})$. Original EMPA data and CL image were obtained at RPI.
ICPMS analysis differed slightly from that analyzed by EMPA. Consequently, for direct comparison it was necessary to interpolate the EMPA data to estimate Ti content near each laser spot; these estimates are tabulated in Table 3. Although sampling of compositionally zoned crystals proved difficult, as evident in the data scatter, the LA-ICPMS and EMPA Ti analyses for these samples are surprisingly well correlated (Fig. 7b).

Overall, these comparisons demonstrate close agreement for Rice LA-ICPMS and RPI EMPA analysis, especially considering the intrinsic heterogeneity of most of the comparison samples. The LA-ICPMS method presents distinct advantages in precision and sensitivity at concentrations below $50 \mathrm{ppm}$. However, orders of magnitude larger sample analysis volume can be a disadvantage for LA-ICPMS when working with strongly zoned crystals and adversely affects resolution of concentration gradients over small distances, such as near crystal rims or near other steep interfaces. Also, all examples confirm a bias toward higher Ti content via ICPMS compared to EMPA analysis; further work using low-Ti standards (and ideally quartz samples of nearidentical matrix composition) is needed to resolve this discrepancy. Nevertheless, we find that ICPMS data are sufficiently precise to evaluate relative variations at concentration ranges observed in natural quartz samples.

\section{DISCUSSION}

A second principal objective of this work was to establish the extent to which the CL spectra for quartz can be used to quantitatively assess the distribution of Ti therein. This is addressed directly in a series of correlation plots (Fig. 8). Again, we note that in two cases CL data were acquired after LA-ICPMS analysis, such that the two datasets correspond to closely adjacent but not identical sample areas. Also, in two cases, LA-ICPMS analysis followed the spectral analysis of each grain and afterward CL data could be integrated precisely from the areas sampled by the laser.

Data for the CMB quartz phenocryst (Fig. 8a) are exceptionally well correlated $\left(R^{2}=0.98\right)$ despite the fact that the data are not exactly spatially congruent. Using the regression equation to calculate Ti contents from $2.7 \mathrm{eV} \mathrm{CL}$ intensities for this sample, the observed LA-ICPMS measure- 

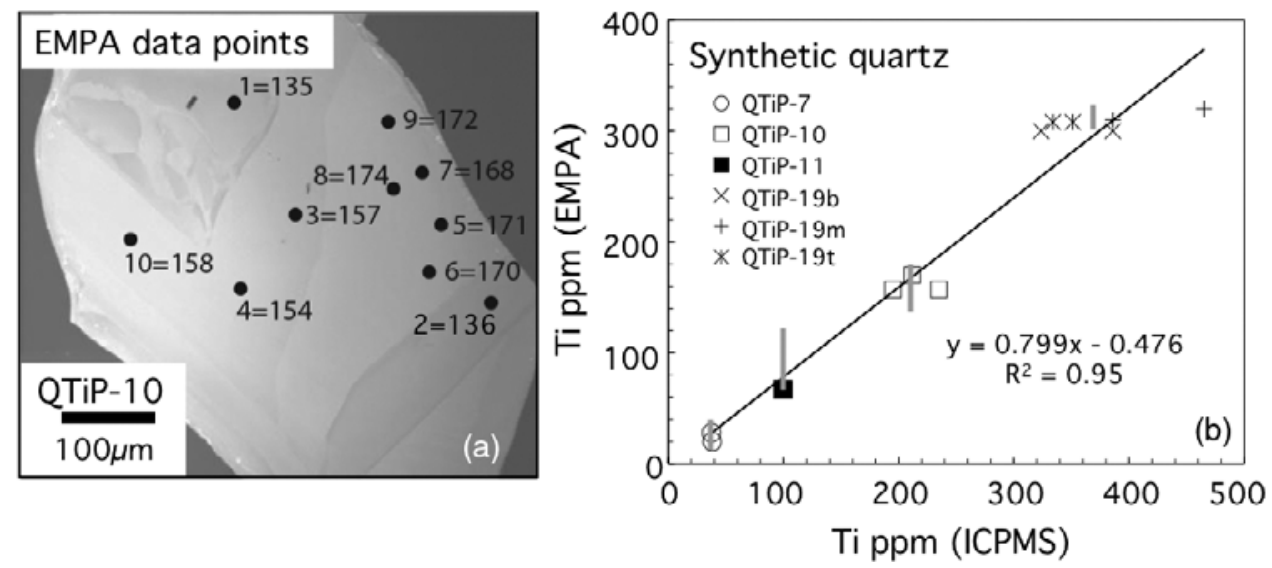

Figure 7. (a) CL image of synthetic quartz QTiP-10 reveals distinct CL domains and heterogeneous distribution of Ti based on EMPA analysis at RPI (see Table 4). (b) Correlation plot showing EMPA versus LA-ICPMS Ti analyses for all analyzed synthetic quartz samples. Although the regression line through all data is very close to a perfect correlation, ICPMS data are systematically higher than EMPA data. In detail there is considerable scatter in LA-ICPMS results, particularly for the highest Ti sample. Also, the range in EMPA data (indicated by vertical gray bars) is significantly greater than the expected analytical precision in some cases-reflecting sample heterogeneity. As indicated in Table 4, EMPA Ti content appears to be bimodal in some samples (QTiP-10 and -11).
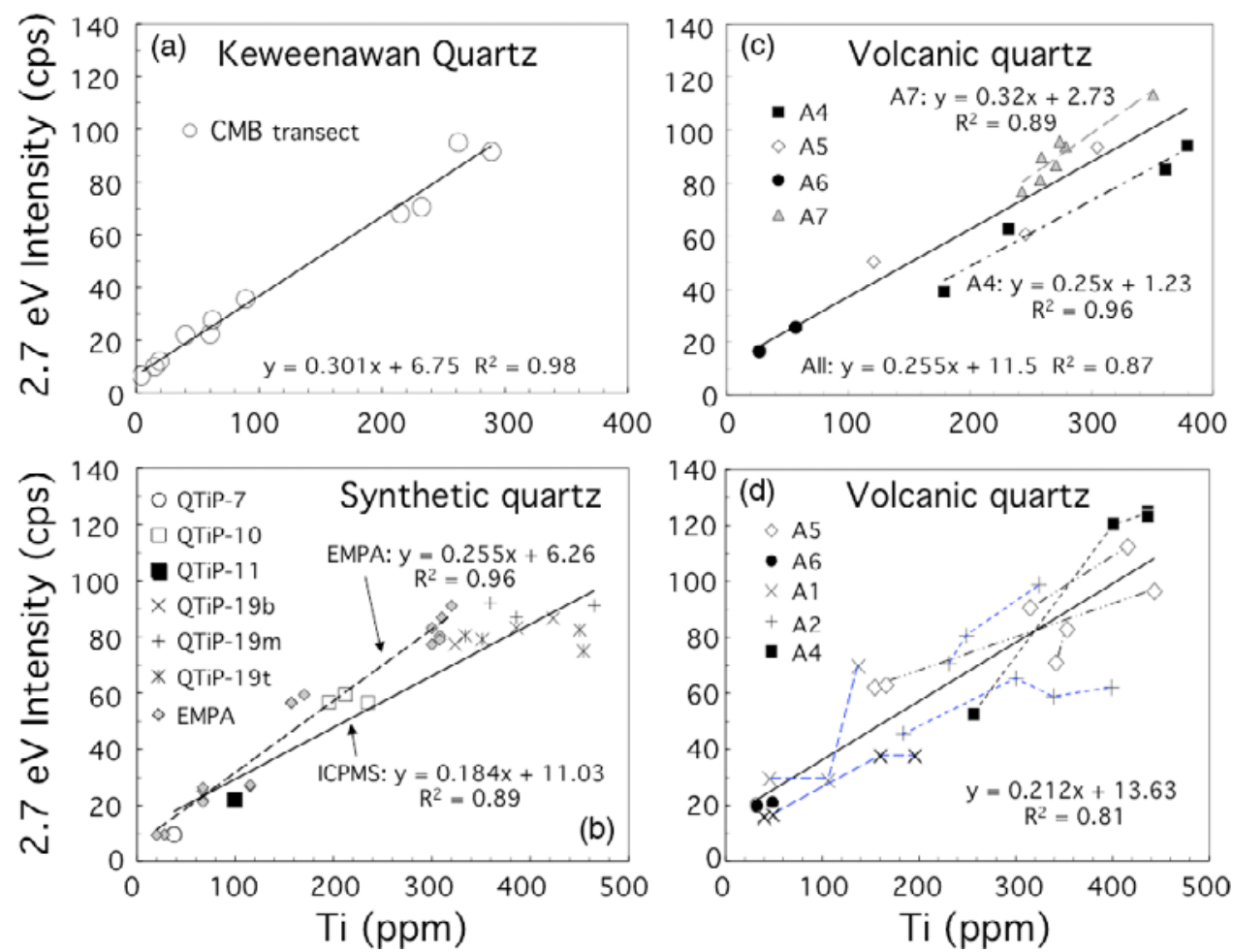

Figure 8. Correlation of $2.7 \mathrm{eV} \mathrm{CL}$ intensity with Ti content of various quartz populations. (a) Data for single crystal in Keweenawan sample CMB, with CL data acquired after LA-ICPMS analysis on adjacent spots. (b) Data for experimentally produced synthetic quartz with CL data acquired first. (c) Data for selected volcanic quartz phenocrysts, with CL data acquired after LA-ICPMS analysis on adjacent spots. (d) Data for selected volcanic quartz phenocrysts, with CL data acquired prior to LA-ICPMS analysis. Dashed lines link multiple analyses from individual grains.

ments are reproduced within $15 \%$ for all but a few points with low concentration (e.g., $\mathrm{Ti}<40 \mathrm{ppm}$ ).

Data for the synthetic quartz samples (Fig. 8b) are also well correlated $\left(R^{2}=0.94\right)$, despite the fact that individual samples are heterogeneous to varying extent. Averages of the individual EMPA data for these samples are provided in Table 4 and, superposed on the figure, they reinforce the general agreement between analytical methods. In this case, the scale of heterogeneity and relative sampling volumes for each method appear not to introduce a significant bias. 
Using the regression between intensity of the $2.7 \mathrm{eV}$ peak and EMPA data, Ti concentration is predicted with better than $30 \%$ accuracy for all but sample QTiP-7, which has the lowest Ti content (ca. $25 \mathrm{ppm}$ ); data for sample QTiP-19 (ca. $300 \mathrm{ppm}$ ) are predicted within better than $10 \%$.

Data for the remaining volcanic quartz samples are more complex than expected. For the first round of analyses (Fig. 8c), the data as a whole are reasonably well correlated $\left(R^{2}=0.87\right)$ but clearly appear to fall into distinct subgroups. In particular, correlations between Ti and CL intensity are significantly stronger for data restricted to single compositionally zoned grains $\left(R^{2} s\right.$ of 0.96 and 0.89 , respectively, for quartz in samples A4 and A7). Data for the second round of analyses are more scattered and exhibit a lower overall correlation $\left(R^{2}=0.81\right)$. In this case, data were obtained for five different samples but, unlike the first case, multiple spots on multiple grains were analyzed for most samples. There appear to be systematic correlations for some grains or parts thereof, but multiple grains from a given sample are not always well correlated. It is also apparent that data from two samples (A4 and A5) have different ranges of CL intensity for the periods of analysis. While this may in part reflect extraction of spectral data from different spots on the grains, the data subsets have similar ranges in Ti content. It is likely that the CL collected after the initial ICPMS analysis contained localized defects induced by the laser, which led to variations in the observed CL response. Stevens-Kalceff (2009) reported changes in the $2.7 \mathrm{eV}$ peak over time due to beam irradiation. Such changes may be ascribed to oxygen-defect centers that, in this case, may have been induced by the laser. Since CL spectra were collected as close as practical to the laser analysis pits, this could have been a significant source of error. For the CL data collected prior to the second round of laser analysis, the variation in CL yield with Ti concentration across a number of quartz grains may be due to one or more of the following:

1. Differences in analysis volume. The laser ablates material from depths over tens of microns compared to the micron-scale depth for the CL emission.

2. Scales of compositional heterogeneity. The volcanic quartz may have varied $\mathrm{Ti}$ contents over submicron length scales, such that the relocation of where the laser analysis had been performed is critical to extraction of exactly corresponding CL spectra. Although the laser analysis regions were carefully selected to be as homogenous as possible, it was not always possible to avoid small-scale heterogeneities-particularly in the subsurface volume sampled by the laser. For example, the quartz CL maps (cf. Figs. 4, 10, and 11) illustrate both heterogeneous regions and fine scale zoning in many samples.

3. Varied controls on CL centers within and between samples. Titanium impurities can occur in a number of radiative and nonradiative configurations in quartz (e.g., $\mathrm{Ti}^{3+}, \mathrm{Ti}^{4+}$, substitutional, and interstitial). The volcanic quartz may contain variable relative proportions of the radiative to nonradiative sites giving rise to a further source of error (Stevens-Kalceff, 2009). On the other hand, Raman spectral data and density functional theory modeling indicate that Ti dominantly substitutes as $\mathrm{Ti}^{4+}$ for $\mathrm{Si}^{4+}$ on tetrahedral coordination sites (four oxygen atoms) in the quartz structure (Thomas et al., 2010). Moreover, there is little evidence for occurrence of $\mathrm{Ti}^{3+}$ in natural samples owing to relatively oxidized redox conditions in the Earth's crust.

These results demonstrate that under ideal conditions it is possible to attain a high correlation between CL spectral intensity $(2.7 \mathrm{eV}$ peak) and $\mathrm{Ti}$ content in quartzparticularly in single crystals for which conditions favor a near-uniform spectral response. However, further work is needed to understand second-order differences in CL response between samples and, in some cases, between individual quartz grains in a given sample. In general, for exacting applications, it seems advisable to calibrate that response on at least a sample-by-sample basis-as is well exemplified by results for the Keweenawan quartz.

\section{Applications}

We next consider potential applications of high-resolution CL spectral analysis to interpretations of the growth history of quartz in magmatic systems, and the underlying petrologic processes recorded during that growth. Evidence for multiple growth stages, possible resorption, and overgrowths of new quartz provide insights into how magmas are aggregated and stored in the crust. Coupled with compositional information on melt inclusions and/or mineral intergrowths, it may be possible to add further compositional and temporal constraints (cf. Matthews et al., 2012; Thomas \& Watson, 2012; Wilson et al., 2012). Development of the PTitaniQ methodology adds another tool for potentially constraining physical conditions for magmatic processes, albeit differences in calibration and interpretation remain to be resolved. In this section we briefly consider examples of the information content in the CL maps and how they may be utilized to enhance petrologic interpretation.

The highly zoned Keweenawan quartz phenocryst is particularly noteworthy because of the intricate zonation that it displays. Figure 9 presents two images of this grain. The first is a map of CL $1.93 \mathrm{eV}$ intensity that shows the core region to be dominated by intrinsic quartz CL. The second image presents a map of $\mathrm{Ti}$ distribution, derived from the $2.7 \mathrm{eV}$ CL peak intensity, based on the strong correlation of these parameters shown in Figure 8a. Individual data points from our LA-ICPMS traverse are plotted on the figure to emphasize the precision of the concentration contours. This map brings out details that cannot be gleaned easily from direct spot analysis. The small dark core region, generally characterized by less than $\sim 15 \mathrm{ppm} \mathrm{Ti}$, is of dubious magmatic origin; it could possibly represent entrained restitic material (i.e., relict unmelted material) from a near-solidus melting regime in the crust. In contrast, the dark blue inner core is interpreted as magmatic in origin as it has euhedral morphology, includes a trapped melt inclu- 

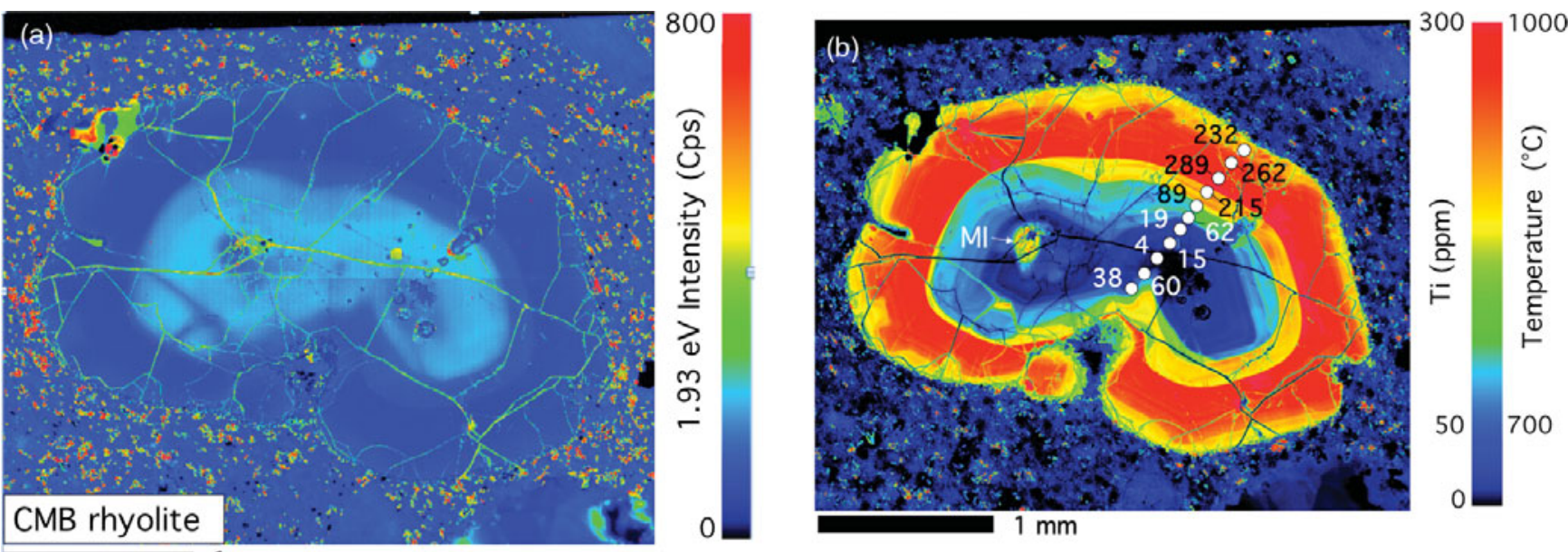

Figure 9. Further views of zoned Keweenawan phenocryst (CMB) seen in Figure 2. (a) Map of $1.93 \mathrm{eV}$ intrinsic CL; note extremely low overall intensity with maxima in core area containing very low $\mathrm{Ti}(<30 \mathrm{ppm})$. (b) Map of Ti distribution throughout the exposed quartz grain obtained from $2.7 \mathrm{eV} \mathrm{CL}$ calibrated against Ti measurements from this study (see Fig. 8a). The new ICPMS data are superposed to illustrate excellent fit in detail with the map. The preliminary temperature estimates were based on the PTitaniQ geothermometer (Thomas et al., 2010) using $a_{\mathrm{TiO}_{2}}=$ 0.15 and nominal pressure of $3 \mathrm{kbar}$. The resulting range in crystallization temperature overlaps $\mathrm{Zr}$ saturation temperatures for melt inclusions in quartz grains from the same locality (cf. Student et al., 2007).
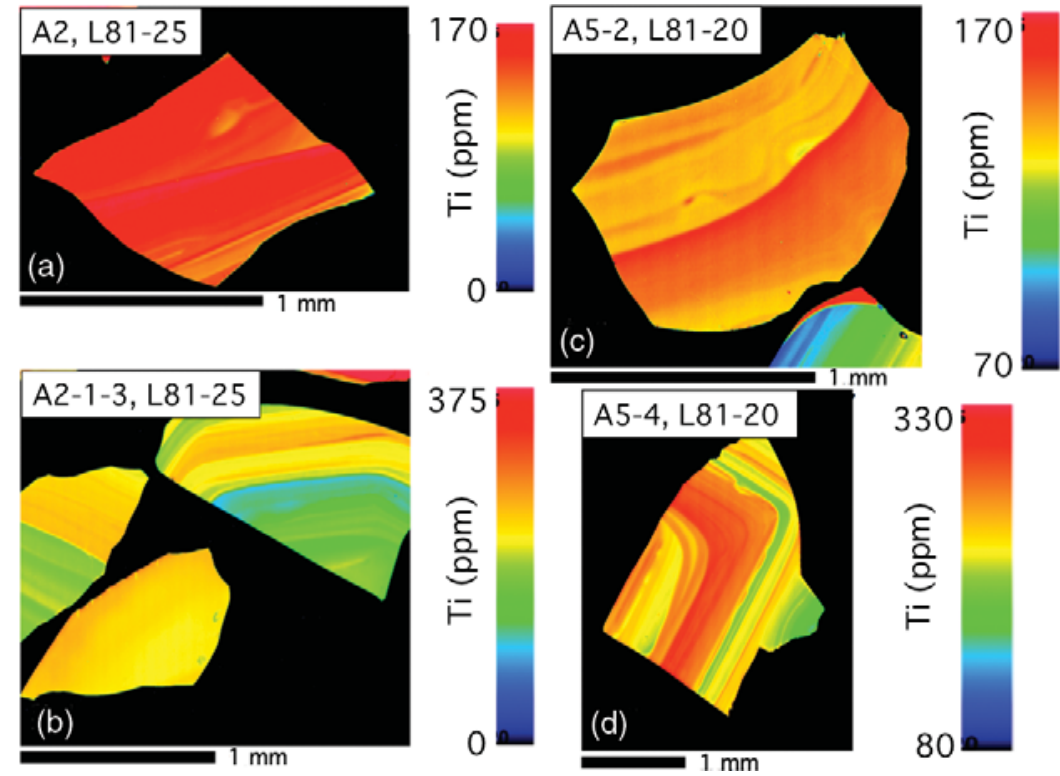

Figure 10. Maps of $2.7 \mathrm{eV}$ CL intensity converted to Ti ppm using analytical data for individual grains: (a, b) sample A2 (L81-25); (c, d) sample A5 (L81-20). All grains are from the same volcanic unit, rhyolite lava of Magic Reservoir (Tmr; Honjo \& Leeman, 1987).

sion (now crystallized), and has fairly uniform Ti content near $50 \mathrm{ppm}$. For illustration, application of the PTitaniQ thermobarometer (using a nominal pressure of $3 \mathrm{kbar}$ and $a_{\mathrm{TiO}_{2}}=\sim 0.15$, as calculated using RMELTS for melt inclusion data from other grains) suggests that such low $\mathrm{Ti}$ contents likely correspond to magmatic temperatures near or below $750^{\circ} \mathrm{C}$; such low-T melts are likely to be water-rich (i.e., near the water-saturated solidus for silicic materials; Johannes \& Holtz, 1996). Subsequent accretion on the euhedral core of higher-Ti quartz (yellow-green region in Fig. 9b) proceeded until concentrations reached $\sim 200 \mathrm{ppm}$; this could reflect combined effects of increasing $\mathrm{T}$ and decompression (Müller et al., 2009; Thomas \& Watson, 2012). The anhedral outer form of this zone (yellow/red interface) suggests a period of resorption, after which a major overgrowth rim (red-orange area) formed with high and relatively uniform Ti content ( $260-290 \mathrm{ppm})$. The latter overgrowth reflects a major change in the magmatic system. Several processes (e.g., magma ascent and decompression, volatile exsolution, magma mixing) or combinations thereof could possibly produce the sharp transition (cf. Liu et al., 2006; Müller et al., 2009; Thomas et al., 2010; Thomas \& Watson, 2012). Finally, the thin outermost rim is characterized by a sharp decrease in Ti to levels near $100 \mathrm{ppm}$; the map best illustrates this, as it was difficult to obtain LAICPMS data near the crystal edge. However, the irregular, 

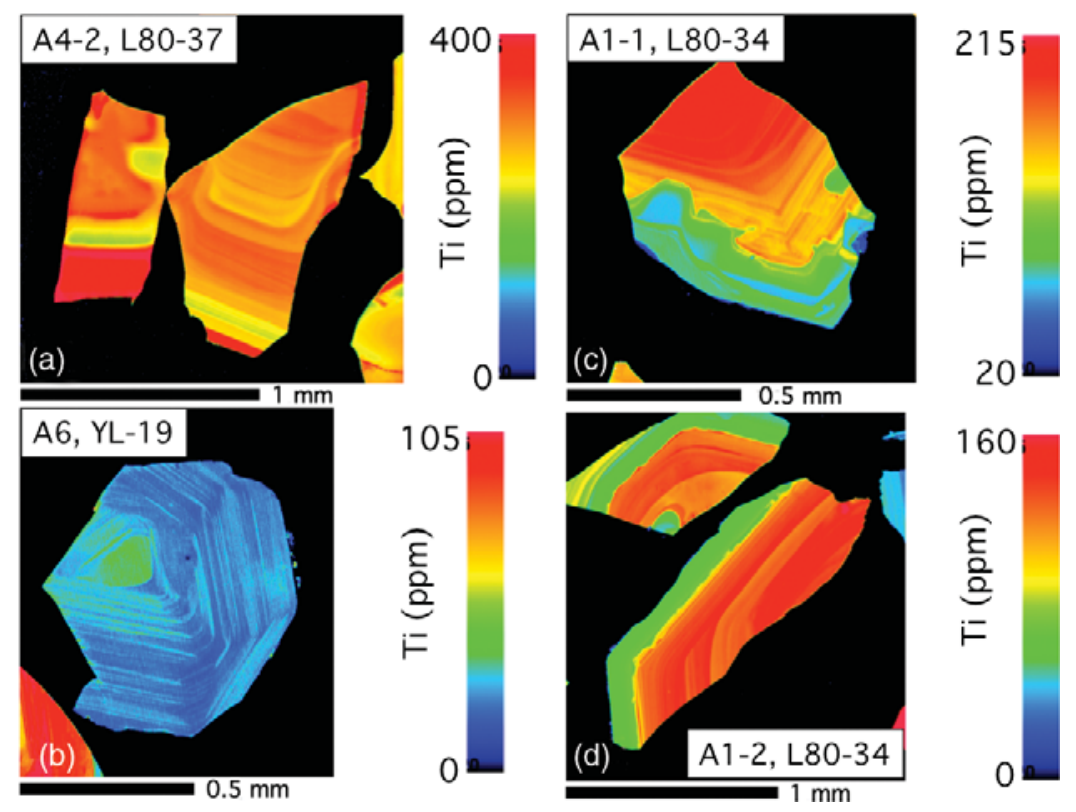

Figure 11. Maps of $2.7 \mathrm{eV}$ CL intensity converted to Ti ppm using analytical data for individual grains: (a) sample A4 (L80-37; rhyolite of Dinosaur Ridge); (b) sample A6 (YL-19, rhyolite of Gibbon Hill, Yellowstone); (c, d) sample A1 (L80-34, rhyolite of Rattlesnake Butte).
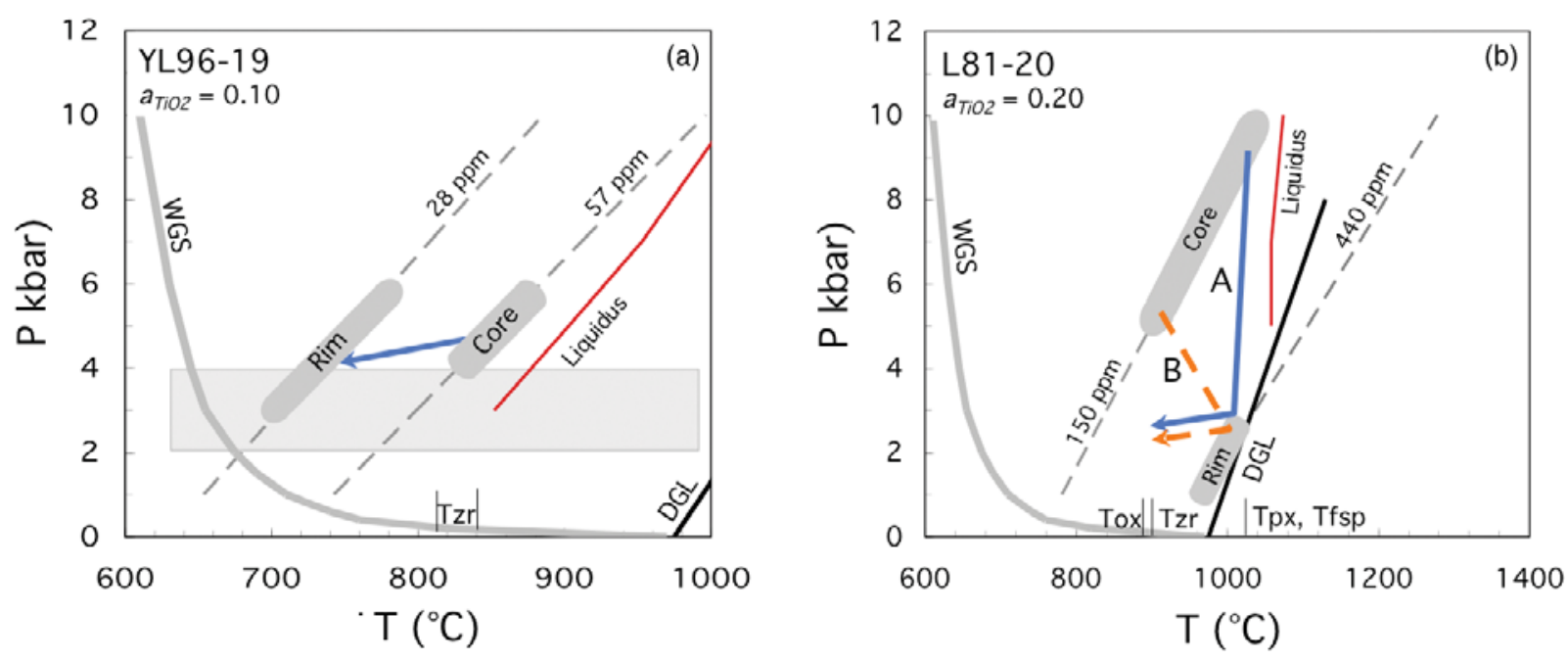

Figure 12. P-T diagrams showing isopleths of Ti content in quartz compositions at indicated $a_{\mathrm{TiO}_{2}}$ values calculated with RMELTS and the PTitaniQ model of Thomas et al. (2010). Loci are shown for the water-saturated "granite" solidus (WGS) and dry "granite" liquidus (DGL) for reference (cf. Holtz et al., 2001). Light-shaded rectangle delimits the range of pressure (ca. 2-4 kbar) over which SRP rhyolite mineral assemblages were experimentally replicated (Almeev et al., 2009, 2012). (a) Gibbon Dome rhyolite $\left(a_{\mathrm{TiO}_{2}}=0.10\right)$, showing isopleths for core (ca. $\left.57 \mathrm{ppm} \mathrm{Ti}\right)$ and rim $(28 \mathrm{ppm})$ compositions. $\mathrm{Zr}$ and $\mathrm{Zr}^{\prime}$ saturation $\mathrm{Ts}\left(\mathrm{Tzr}\right.$; ca. $820-860^{\circ} \mathrm{C}$ ) and liquidus curve (calculated with RMELTS assuming 3\% $\mathrm{H}_{2} \mathrm{O}$ in melt and NNO redox buffer) provide constraints on temperature. Bold arrow indicates general P-T trend inferred during progressive quartz growth. Small fluctuations in Ti in the broad rim of this quartz can be explained by subtle temperature and/or composition fluctuations within the magma reservoir. (b) Similar diagram for a high temperature MREC rhyolite (L81-20) with $a_{\mathrm{TiO}_{2}}(0.20)$ showing isopleths for core (ca. $150 \mathrm{ppm} \mathrm{Ti}$ ) and maximum-Ti overgrowth ("Rim," $440 \mathrm{ppm}$ ) compositions. Independent T estimates based on oxide (Tox), pyroxene (Tpx), and feldspar (Tfsp) thermometry, and Zr saturation (Tzr) suggest a maximum magmatic temperature near $1,020^{\circ} \mathrm{C} . \mathrm{T}$ liquidus curve for this sample is calculated with RMELTS assuming $1.5 \% \mathrm{H}_{2} \mathrm{O}$ in melt and NNO redox buffer. Two hypothetical P-T paths are suggested to explain variations in quartz composition. A (bold solid trend) invokes simple decompression between core and overgrowth stages; B (bold dashed trend) invokes heating and decompression.

variably embayed contact between outer and inner zones of the rim indicate that the grain was undergoing dissolution in a magma reservoir for some time, then cooled relatively quickly (i.e., preserving a steep concentration gradient), during which time the outermost rim formed.
Other quartz Ti maps are presented to further illustrate the information content they convey (Figs. 10, 11). Calibrations of the spectral maps are based on a limited number of analyses (cf. Table 3) for the highlighted grains, and interpretation is enhanced by application of the PTitaniQ thermo- 
barometer, where values of $a_{\mathrm{TiO}_{2}}$ are calculated using RMELTS assuming that bulk rock compositions approximate the magmatic liquids. Figure 10 presents Ti maps for representative grains from two samples of a high-T MREC rhyolite lava flow (central Snake River Plain). This unit is interpreted to represent a rhyolitic magma into which approximately $10 \%$ basaltic magma was mixed (Honjo \& Leeman, 1987). The quartz grains in this volcanic unit are strongly zoned and have among the highest $\mathrm{Ti}$ contents measured (up to $443 \mathrm{ppm}$ ), consistent with inferred magmatic temperatures greater than $1,000^{\circ} \mathrm{C}$ (Honjo et al., 1992). Unsurprisingly, the Ti maps reflect complex growth histories, albeit the record is incomplete in any one grain because of fragmentation. However, it is evident that crystal growth varied from relatively low- $\mathrm{Ti}$ cores to maximum- $\mathrm{Ti}$ intermediate zones and, finally, reverted back to lower-Ti rims-similar to zoning in the Keweenawan quartz.

Figure 11 presents images of rhyolite dome samples from the central Snake River Plain (A1, A6) and from Yellowstone (YL-19). Compared to the previous example, mineral thermometry indicates significantly lower temperatures for these samples (Honjo et al., 1992; Vazquez et al., 2009) although such information is not currently available for sample A4. Very distinct growth histories are evident in these samples. Multiple grains in sample A1 have high-Ti cores (up to $200 \mathrm{ppm}$; consistent with temperatures $>900^{\circ} \mathrm{C}$ ) and normal overgrowths of lower-Ti quartz (ca. $40 \mathrm{ppm}$ ) with a sharp interface between these domains. Thus, quartz growth began in a relatively hot magma followed by rapid cooling, perhaps triggered by its ascent to a shallow, lower- $\mathrm{T}$ magma reservoir prior to eruption. In contrast, sample A4 quartz records a significantly warmer magma with $\mathrm{Ti}$ contents exceeding $400 \mathrm{ppm}\left(\mathrm{ca} .>1000^{\circ} \mathrm{C}\right)$. The mapped grains record frequent oscillations, with maximum $\mathrm{Ti}$ in the rims, suggestive of a strong heating event just prior to eruption. Given the elevated temperatures, this could signify that eruption was triggered by emplacement of a new batch of hotter magma into the reservoir. Sample A6 is distinctive in that it has relatively low Ti overall (ca. 27-60 ppm), with highest values in the core region. In this case, the original magma is inferred to have been relatively cool compared to the previous examples, and the bulk of the quartz apparently grew under cooler conditions than the core. However, fine oscillation in $\mathrm{Ti}$ content is apparent and signifies a protracted cooling history, perhaps with minor thermal perturbations, consistent with dynamic and complex scenarios that have been proposed for the magma system beneath Yellowstone (cf. Vazquez et al., 2009; Girard \& Stix, 2010).

Finally, we attempt to integrate the textural observations with constraints derived from the Ti systematics. To this end, it is instructive to consider the interrelations among magma composition (Ti content and $a_{\mathrm{TiO}_{2}}$ ), pressure, and temperature. Using equation (9) of Thomas et al. (2010) and $a_{\mathrm{TiO}_{2}}$ values calculated using RMELTS, it is possible to determine the loci of Ti isopleths in P-T space (Fig. 12). It should be noted that other methods of estimating $a_{\mathrm{TiO}_{2}}$ (e.g., based on assumed equilibrium among melt and coexisting magnetite and ilmenite) tend to produce somewhat higher values than RMELTS, and their use will shift positions of the isopleths upward in the diagram. However, as discussed by Ghiorso and Gualda $(2011,2012)$ and Thomas and Watson (2012), there is reason to question mineral-based estimates of activity as the oxide minerals in many rhyolites do not appear to represent equilibrium compositions. As we will show, the RMELTS-based estimates combined with PTitaniQ appear to predict realistic if not unique scenarios for quartz growth.

We first consider the Gibbon Hill rhyolite (YL-19; Fig. 12a), which contains "normally zoned" quartz with $\mathrm{Ti}$ decreasing from core to rim ( $\sim 60$ to $27 \mathrm{ppm})$. This style of zoning is commonly observed and can be explained most easily by cooling of the host magma at constant or decreasing pressure. In this case, constraints on formation of the quartz core are provided by $\mathrm{Zr}$ saturation temperatures near $\sim 820-860^{\circ} \mathrm{C}$, and by the RMELTS calculated liquidus for melts of YL96-19 composition assuming a maximum of 3\% $\mathrm{H}_{2} \mathrm{O}$ in the melt (inferred from compositions of melt inclusions in Yellowstone rhyolites; Gansecki, 1998). Offset of the $57 \mathrm{ppm} \mathrm{Ti}$ isopleths to lower temperatures with respect to the calculated liquidus is consistent with experiments (Almeev et al., 2009, 2012) on similar rhyolites in which quartz forms ca. $50^{\circ} \mathrm{C}$ below the liquidus (i.e., it forms later than clinopyroxene and sanidine feldspar). These factors are consistent with initial quartz growth from a water-bearing melt at pressures as low as $\sim 4 \mathrm{kbar}$, and possibly as high as $\sim 6 \mathrm{kbar}$ (assuming magmatic temperatures up to $\sim 900^{\circ} \mathrm{C}$, or near the upper limit for all Yellowstone rhyolites). Rim formation could have occurred over a range of temperatures depending on the exact cooling path (only one simple example is shown in the figure). However, the breadth of the rim and subtle oscillatory variations in $\mathrm{Ti}$ content therein (Fig. 11b) suggest that the quartz resided in a magma reservoir at conditions near the $27 \mathrm{ppm} \mathrm{Ti}$ isopleth for some time prior to eruption. It is also possible that the quartz cores formed in a distinct warm magma and were entrained as xenocrysts (foreign crystals) or restite (relicts from partially remelting an older silicic intrusion) in a later magma from which the broad rim crystallized (cf. Girard \& Stix, 2010; Watts et al., 2012). In either case, despite uncertainty as to the exact pressure, the rims formed under cooler conditions than the core.

The second example considered is the complex high-T MREC rhyolite (Tmr; L81-20; Figs. 11c, 11d) that has high-Ti quartz overgrowths (up to $\sim 440 \mathrm{ppm}$ ) on low-Ti cores $(\sim 150 \mathrm{ppm})$; although outermost rims revert to lower $\mathrm{Ti}$ $(\sim 200 \mathrm{ppm})$ compositions, the step-like increase is a common feature in volcanic quartz and such "reverse zoning" is often attributed to heating (cf. Wark et al., 2007). Ti isopleths are plotted for the end member core and rim compositions (Fig. 12b). Theoretically, quartz of these compositions could form at any P-T conditions along the respective isopleths. Independent temperature constraints ( $\mathrm{Zr}$ saturation, 2-pyroxene, and 2-feldspar thermometers; RMELTS liquidus calculations assuming a maximum of $1.5 \% \mathrm{H}_{2} \mathrm{O}$ in 
the magma, cf. Almeev et al., 2012) imply that actual conditions are limited to the shaded regions along the isopleths. These are also bounded roughly by the schematic "dry granite liquidus," which crosses the $440 \mathrm{ppm}$ isopleth and establishes a firm upper limit on temperature for formation of the high-Ti overgrowth. If core formation is also limited by the aforementioned temperature constraints, then we infer that this occurred at higher pressures (ca. $>6 \mathrm{kbar}$ ); an upper limit is near $9 \mathrm{kbar}$ as the $150 \mathrm{ppm}$ isopleth approaches within $50^{\circ} \mathrm{C}$ of the calculated rhyolite liquidus. Two scenarios are outlined to explain the observed zoning. The first ("A") involves decompression along a hypothetical path, during which partial resorption of the core occurs (cf. Müller et al., 2009), followed by storage of the magma at low pressure (ca. $\leq 3 \mathrm{kbar}$ ) during which the overgrowth forms. The second scenario ("B") involves a combination of decompression and heating by hot intrusive basalt (Honjo \& Leeman, 1987). In this case, the initial rhyolite could have crystallized core quartz at pressures substantially lower (possibly as low as ca. $3 \mathrm{kbar}$ ), in which case path " $\mathrm{B}$ " could be as extreme as an isobaric spike in temperature. In both cases, after formation of the high-Ti overgrowth, a period of cooling is required to form the outer rim; oscillations in $\mathrm{Ti}$ content likely signify intermittent fluctuations in temperature during the final repose.

It is acknowledged that the above scenarios are generalized and based on some assumptions that require further testing. For example, magma composition is not necessarily constant during the entire growth history of the quartz phenocrysts, in which case $a_{\mathrm{TiO}_{2}}$ values and water content could have varied causing shifts in the isopleths and liquidus curves. These issues can be addressed with careful petrologic study of melt and mineral inclusions in the quartz. However, our objective here is to illustrate how $\mathrm{Ti}$ distributions in quartz can potentially enhance our understanding of complex magmatic systems.

\section{CONCLUSIONS}

Two principal goals of this study were to evaluate analytical methods for measuring Ti distributions in natural quartz and methods for quantifying CL images thereof. LA-ICPMS and EMPA methods are widely used and both are useful. The latter provides higher spatial resolution but has lower sensitivity. Also, at Ti concentrations below ca. 50 ppm, poorer precision is a limitation for exacting applications. LA-ICPMS has greater sensitivity but poorer spatial resolution due to the large sample volume that is excited during analysis; this is disadvantageous when working with heterogeneous samples. However, the ability to simultaneously measure a large number of other trace elements via LAICPMS is a significant advantage. Although both methods provide high quality data for $\mathrm{Ti}$, it is apparent that better standards are needed at low concentration levels to improve calibration and to evaluate matrix effects.

High-resolution CL spectral analysis provides remarkable images of deconvolved spectral components and, in combination with direct analysis, can be used to produce detailed maps of spatial variation in Ti content based on intensity of the $2.7 \mathrm{eV}$ peak. This work demonstrates that other resolvable components of the CL spectra vary in relative intensity depending on the absolute intensity of the $2.7 \mathrm{eV}$ peak, with the following consequences. First, the total CL intensity provides only a qualitative approximation for Ti content. Second, other CL excitons can contribute disproportionately to the $2.7 \mathrm{eV}$ peak such that, at low concentrations of $\mathrm{Ti}$, the correlation between resolved peak intensity and Ti content is degraded. Despite this, we note very good correlation between Ti content and intensity of the $2.7 \mathrm{eV}$ peak for single quartz grains, especially when there is a large range in Ti. On the other hand, correlation lines are sometimes offset for grains from different samples, and in some cases we observe variability in grains within a given sample. To some extent this can be attributed to nonuniform surface conditions, but other factors likely contribute. For example, differences in internal structure (e.g., defect numbers and type), concentrations of other trace constituents $\left(\mathrm{H}_{2} \mathrm{O}, \mathrm{Al}\right.$, $\mathrm{Fe}$, etc.), and artifacts of radiation damage (electron beam, laser) may be contributing factors. Consequently, it is prudent to calibrate CL-based maps with direct analyses insofar as possible. With the hyperspectral system at CSIRO, it is possible to produce detailed concentration profiles of compositional variations at the $2-\mu \mathrm{m}$ scale. Back tests suggest that $\mathrm{Ti}$ concentrations can be predicted with accuracy better than $15 \%$ where concentration levels exceed $40 \mathrm{ppm}$.

Regarding applications of the data, a fundamental question concerns how Ti variations in quartz respond to specific magmatic processes. The ability to map subtle compositional variations in fine detail via $\mathrm{CL}$ images is a powerful tool that can help quantify physical conditions and rates (e.g., via analysis of diffusion profiles; cf. Cherniak et al., 2007; Wark et al., 2007; Matthews et al., 2012) attending magmatic processes. Combination of quantitative modeling and textural analysis offers a means of deducing conditions of magma formation, storage, ascent, and mixing. To reach the full potential of these developments, controversies regarding calibration of Ti solubility in quartz and related thermodynamic parameters must be resolved.

\section{ACKNOWLEDGMENTS}

W.P.L. thanks the Department of Mineral Sciences, Smithsonian Institution for access to facilities and assistance with sample preparation, the National Science Foundation (NSF) for providing time to conduct this research while employed there, and Ilya Bindeman for providing the Yellowstone quartz separates. J.B.T. acknowledges support from the NSF (grant number EAR-0440228 to E.B. Watson) for experimental studies on the solubility of $\mathrm{Ti}$ in minerals. J.J.S. thanks Bob Bodnar and Scott Mutchler for access to VPI facilities and for analytical support. The authors thank C. Davidson (CSIRO) for preparing samples for CL analysis. We also thank Andreas Audétat and an anonymous reviewer for detailed reviews that were of great help in improving the article. 


\section{REFERENCES}

Almeev, R., Holtz, F., Kuschel, L., Nash, B. \& Cathey, H. (2009). Experimental constraints on rhyolite magma genesis, Yellowstone hotspot. Geochim Cosmochim Acta 73(12), A30.

Almeev, R.R., Bolte, T., Nash, B.P., Holtz, F., Erdmann, M. \& Cathey, H.E. (2012). High temperature, low $\mathrm{H}_{2} \mathrm{O}$ silicic magmas of the Yellowstone hotspot: An experimental study, J Petrol 53, 1837-1866.

Anderson, J.L. \& SMith, D.R. (1995). The effects of temperature and $f_{\mathrm{O} 2}$ on the Al-in-hornblende barometer. Am Mineral 80, 549-559.

Andrews, G.D.M., Branney, M.J., Bonnichsen, B. \& McCurry, M. (2009). Rhyolitic ignimbrites in the Rogerson Graben, southern Snake River Plain volcanic province: Volcanic stratigraphy, eruption history and basin evolution. Bull Volcanol 70, 269-291.

Bindeman, I.N. \& VAlley, J.W. (2001). Low-d ${ }^{18}$ O rhyolites from Yellowstone: Magmatic evolution based on analyses of zircons and individual phenocrysts. J Petrol 42, 1491-1517.

Bonnichsen, B., Leeman, W.P., Honjo, N., McIntosh, W.C. \& Godchaux, M.M. (2008). Miocene silicic volcanism in southwestern Idaho: Geochronology, geochemistry, and evolution of the central Snake River Plain. Bull Volcanol 70, 315-342.

Campbell, M.E., Hanson, J.B., Minarik, W.G. \& Stix, J. (2009). Thermal history of the Bandelier magmatic system: Evidence for magmatic injection and recharge at 1.61 Ma as revealed by cathodoluminescence and titanium geothermometry. J Geol 117, 469-485.

Cathey, H.E. \& Nash, B.P. (2004). The Cougar Point Tuff: Implications for thermochemical zonation and longevity of hightemperature, large-volume silicic magmas of the Miocene Yellowstone hotspot. J Petrol 45, 27-58.

Cathey, H.E. \& Nash, B.P. (2009). Pyroxene thermometry of rhyolite lavas of the Bruneau-Jarbidge eruptive center, Central Snake River Plain. J Volcanol Geotherm Res 188, 173-185.

Cherniak, D.J., Watson, E.B. \& Wark, D.A. (2007). Ti diffusion in quartz. Chem Geol 236, 65-74.

Ellis, B.S. \& Wolff, J.A. (2010). Petrologic constraints on the development of a large-volume, high temperature, silicic magma system: The Twin Falls eruptive centre, central Snake River Plain. Lithos 120, 475-489.

Ellis, B.S. \& WolfF, J.A. (2012). Complex storage of rhyolite in the central Snake River Plain. J Volcanol Geotherm Res 211-212, $1-11$.

Flem, B., Larsen, R.B., Grimstvedt, A. \& Mansfeld, J. (2002). In situ analysis of trace elements in quartz by using laser ablation inductively coupled plasma mass spectrometry. Chem Geol 182, 237-247.

GANSECKI, C.A. (1998). 40Ar/39Ar geochronology and pre-eruptive geochemistry of the Yellowstone Plateau Volcanic Field rhyolites. PhD Dissertation. Stanford, CA: Stanford University.

Ghiorso, M.S. \& GuALDA, G.A.R. (2011). A method for estimating the activity of titania in magmatic liquids from the compositions of coexisting rhombohedral and cubic iron-titanium oxides. Eos, Trans Am Geophys Union 91, Fall Meeting Abst. V11A-2486.

Ghiorso, M.S. \& GuALDA, G.A.R. (2012). A method for estimating the activity of titania in magmatic liquids from the compositions of coexisting rhombohedral and cubic iron-titanium oxides. Contrib Mineral Petrol doi:10.1007/s00410-012-0792-y.

Girard, G. \& STIX, J. (2010). Rapid extraction of discrete magma batches from a large differentiating magma chamber: The
Central Plateau Member rhyolites, Yellowstone Caldera, Wyoming. Contrib Mineral Petrol 160, 441-465.

Götze, J., Plötze, M., Graupner, T., Hallbauer, D.K. \& Bray, C.J. (2004). Trace element incorporation into quartz: A combined study by ICP-MS, electron spin resonance, cathodoluminescence, capillary ion analysis, and gas chromatography. Geochim Cosmochim Acta 68, 3741-3759.

Götze, J., Plötze, M. \& Habermann, D. (2001). Origin, spectral characteristics and practical applications of the cathodoluminescence of quartz-A review. Mineral Petrol 71, 225-250.

Götze, J., Plötze, M. \& Trautmann, T. (2005). Structure and luminescence characteristics of quartz from pegmatites. Am Mineral 90, 13-21.

Gualda, G.A.R., Ghiorso, M.S., Lemons, R.V. \& Carley, T.L. (2012). Rhyolite-MELTS: A modified calibration of MELTS optimized for silica-rich, fluid-bearing magmatic systems. J Petrol 53, 875-890.

Harrowfield, I.R., MacRae, C. \& Wilson, N.C. (1993). Chemical imaging in electron microprobes. In Proceedings of the 27th Annual MAS Meeting 1993, pp. 547-548. New York: Microbeam Analysis Society.

Holness, M.B. \& WATT, G.R. (2001). Quartz recrystallization and fluid flow during contact metamorphism: A cathodoluminescence study. Geofluids 1, 215-228.

Holtz, F., Johannes, W., Tamic, N. \& Behrens, H. (2001). Maximum and minimum water contents of granitic melts generated in the crust: A reevaluation and implications. Lithos 56, 1-14.

Honjo, N., Bonnichsen, B., Leeman, W.P. \& Stormer, J.C. (1992). Mineralogy and geothermometry of high-temperature rhyolites from the central and western Snake River Plain. Bull Volcanol 54, 220-237.

Honjo, N. \& Leeman, W.P. (1987). Origin of hybrid ferrolatite lavas from the Magic Reservoir eruptive center, Snake River Plain, Idaho. Contrib Mineral Petrol 96, 163-177.

HuAng, R. \& Audétat, A. (2012). The titanium-in-quartz (TitaniQ) thermobarometer: A critical examination and re-calibration. Geochim Cosmochim Acta 84, 75-89.

Johannes, W. \& Holtz, F. (1996). Petrogenesis and Experimental Petrology of Granitic Rocks. Berlin: Springer Verlag.

Kohn, M.J. \& Northrup, C.J. (2009). Taking mylonites' temperatures. Geology 37, 47-50.

Landtwing, M. \& Pettke, T. (2005). Relationships between SEMcathodoluminescence response and trace element composition of hydrothermal vein quartz. Am Mineral 90, 122-131.

Larsen, R.B., Jacamon, F. \& Krontz, A. (2009). Trace element chemistry and textures of quartz during the magmatichydrothermal transition of Oslo Rift granites. Mineral Mag 73, 691-707.

LeEman, W.P. (1982). Geology of the Magic Reservoir area, Snake River Plain. Idaho Bur Mines Geol Bull 26, 369-376.

Leeman, W.P., Annen, C. \& Dufek, J. (2008). Snake River PlainYellowstone silicic volcanism: Implications for magma genesis and magma fluxes. Geol Soc London Spec Publ 304, 235-259.

Leeman, W.P. \& LeE, C.-T.A. (2008). Taking the temperature of rhyolites from the Yellowstone hotspot track: Evaluation of the Ti-in-Quartz method. Geochim Cosmochim Acta 72(12), A906.

Lehmann, K., Berger, A., Gotte, T., Ramseyer, K. \& WiedenBECK, M. (2009). Growth-related zonations in authigenic and hydrothermal quartz characterized by SIMS-, EPMA-, SEMCL- and SEM-CC-imaging. Mineral Mag 73, 633-643.

Liu, Y., Anderson, A.T., Wilson, C.J.N., Davis, A.M. \& Steele, I.M. (2006). Mixing and differentiation in the Oruanui rhyolite 
magma, Taupo, New Zealand: Evidence from volatiles and trace elements in melt inclusions. Contrib Mineral Petrol 151, 71-87.

Longerich, H.P., JACKson, S.E. \& Gunther, D. (1996). Laser ablation inductively coupled plasma mass spectrometric transient signal data acquisition and analyte concentration calculation. J Anal At Spectrom 11, 899-904.

Luff, B.J. \& Townsend, P.D. (1990). Cathodoluminescence of synthetic quartz. J Phys-Condens Mat 2, 8089-8097.

MacRae, C.M., Wilson, N.C. \& Brugger, J. (2008). Hyperspectral cathodoluminescence microanalysis-Mapping at the part per million level. IUMAS IV Conference, Perth, Australia, February $10-15,2008$.

MacRae, C.M., Wilson, N.C. \& Brugger, J. (2009). Quantitative cathodoluminescence mapping with application to a Kalgoorlie Scheelite. Microsc Microanal 15, 222-230.

MacRae, C.M., Wilson, N.C., Johnson, S.A., Phillips, P.L. \& Отsuki, M. (2005). Hyperspectral mapping-Combining cathodoluminescence and X-ray collection in an electron microprobe. Microsc Res Techniq 67(5), 271-277.

Marshall, D.J. (1988). Cathodoluminescence of Geological Materials. London: Unwin Hyman Ltd.

Mason, R.A. (1987). Ion microprobe analysis of trace elements in calcite with an application to the cathodoluminescence zonation of limestone cements from the Lower Carboniferous of South-Wales, UK. Chem Geol 64, 209-224.

Mason, R., Clouter, M. \& Goulding, R. (2005). The luminescence decay-time of $\mathrm{Mn}^{2+}$ activated calcite. Phys Chem Mineral 32, 451-459.

Matthews, N.E., Pyle, D.M., Smith, V.C., Wilson, C.J.N., HuBer, C. \& VAn Hinsberg, V. (2012). Quartz zoning and the pre-eruptive evolution of the $\sim 340 \mathrm{ka}$ Whakamaru magma systems, New Zealand. Contrib Mineral Petrol 163, 87-107.

Monecke, T., Kempe, U. \& Götze, J. (2002). Genetic significance of the trace element content in metamorphic and hydrothermal quartz: A reconnaissance study. Earth Planet Sci Lett 202, 709-724.

Morrison, C.A., Lambert, D.D., Morrison, R.J.S., Ahlers, W.W. \& NicholLs, I.A. (1995). Laser ablation-inductively coupled plasma-mass spectrometry: An investigation of elemental responses and matrix effects in the analysis of geostandard materials. Chem Geol 119, 13-29.

Müller, A., Herrington, R., Armstrong, R., Seltman, R., Kirwin, D., Stenina, N. \& Kronz, A. (2010). Trace elements and cathodoluminescence of quartz in stockwork veins of Mongolian porphyry-style deposits. Mineral Depos 45, 707-727.

Müller, A., Kronz, A. \& Breiter, K. (2002). Trace elements and growth patterns in quartz: A fingerprint of the evolution of the subvolcanic Podlesí Granite System (Krušnéhory Mts., Czech Republic). Bull Czech Geol Surv 77, 135-145.

Müller, A., René, M., Behr, H.-J. \& Kronz, A. (2003a). Trace elements and cathodoluminescence of igneous quartz in topaz granites from the Hub Stock (Slavkovsky Les Mts., Czech Republic). Mineral Petrol 79, 167-191.

Müller, A., van den Kerkhof, A.M., Behr, H.-J., Kronz, A. \& Koch-Müller, M. (2009). The evolution of late-Hercynian granites and rhyolites documented by quartz-A review. Earth Env Sci T R Soc 100(Special issue 1-2), 185-204.

Müller, A., Wiedenbeck, M., Van den Kerkhof, A.M., Kronz, A. \& Simon, K. (2003b). Trace elements in quartz: A combined electron microprobe, secondary ion mass spectrometry, laser ablation ICPMS, and cathodoluminescence study. Eur J Mineral 15, 747-763.
Peppard, B.T., Steele, I.M., Davis, A.M., Wallace, P.J. \& Anderson, A.T. (2001). Zoned quartz phenocrysts from the rhyolitic bishop tuff. Am Mineral 86, 1034-1052.

Perkins, M.B. \& Nash, B.P. (2002). Explosive silicic volcanism of the Yellowstone hotspot: The ash fall tuff record. Geol Soc Am Bull 114, 367-381.

Perny, B., Eberhardt, P., Ramseyer, K., Mullis, J. \& Pankrath, R. (1992). Microdistribution of $\mathrm{Al}, \mathrm{Li}$, and $\mathrm{Na}$ in quartz: Possible causes and correlation with short-lived cathodoluminescence. Am Mineral 77, 534-544.

Remond, G., Phillips, M.R. \& Roque-Carmes, C. (2000). Importance of instrumental and experimental factors on the interpretation of cathodoluminescence data from wide band gap materials. In Cathodoluminescence in Geosciences, Pagel, M., Barbin, V., Blanc, P. \& Ohnenstetter, D. (Eds.), pp. 59-126. Heidelberg: Springer Verlag.

Rusk, B.G., Koenig, A. \& Lowers, H. (2011). Visualizing trace element distribution in quartz using cathodoluminescence, electron microprobe, and laser ablation-inductively coupled plasmamass spectrometry. Am Mineral 96, 703-708.

Rusk, B.G., Lowers, H.A. \& Reed, M.H. (2008). Trace elements in hydrothermal quartz: Relationships to cathodoluminescent textures and insights into vein formation. Geology 36, 547-550.

Rusk, B.G., Reed, M.H., Dilles, J.H. \& Kent, A.J.R. (2006). Intensity of quartz cathodoluminescence and trace element content in quartz from the porphyry copper deposit at Butte, Montana. Am Mineral 91, 1300-1312.

Sato, K. \& Santosh, M. (2007). Titanium in quartz as a record of ultrahigh-temperature metamorphism: The granulites of $\mathrm{Ku}$ rur, southern India. Mineral Mag 71, 143-154.

Shane, P., Smith, V.C. \& Nairn, I. (2008). Millennial timescale resolution of rhyolite magma recharge at Tarawera volcano: Insights from quartz chemistry and melt inclusions. Contrib Mineral Petrol 156, 397-411.

Smith, R.B., Jordan, M., Steinberger, B., Puskas, C.M., Farrell, J., Waite, G.P., Husen, S., Chang, W.L. \& O’Connell, R.O. (2009). Geodynamics of the Yellowstone Hotspot and Mantle plume: Seismic and GPS imaging, kinematics, and mantle flow. J Volcanol Geotherm Res 188, 26-56.

SPEAR, F.S. \& WARK, D.A. (2009). Cathodoluminescence imaging and titanium thermometry metamorphic quartz. J Metamorph Geol 27, 187-205.

Stevens-Kalceff, M.A. (2009). Cathodoluminescence microcharacterization of point defects in $\alpha$-quartz. Mineral Mag 73, 585-605.

Stevens-Kalceff, M.A. \& Phillips, M.R. (1995). Cathodoluminescence micro-characterization of the defect structure of quartz. Phys Rev B 52, 3122-3134.

Storm, L.C. \& Spear, F.S. (2009). Application of the titanium-inquartz thermometer to pelitic migmatites from the Adirondack Highlands, New York. J Metamorph Geol 27, 479-494.

Student, J.J., Wark, D.A., Mutchler, S.R. \& Bodnar, R.J. (2006). Pristine rhyolite glass melt inclusions in quartz phenocrysts from the $1.1 \mathrm{Ga}$ midcontinent rift system, Keweenaw Peninsula, Michigan. Eos, Trans Am Geophys Union 87, Fall Meeting Suppl., Abstract V23C-0619.

Student, J.J., WARK, D.A., Mutchler, S.R. \& Bodnar, R.J. (2007). Thermal evolution of Proterozoic $(>1 \mathrm{Ga})$ rhyolite magma based on analysis of melt inclusions and trace elements in quartz from the Keweenaw Peninsula of Michigan. Institute on Lake Superior Geology 53rd Annual Meeting, Proceedings and Abstracts, 53(P1), 77-78. 
Suttner, L.J. \& Leininger, R.K. (1972). Comparison of trace element content of plutonic, volcanic and metamorphic quartz from southwestern Montana. Bull Geol Soc Am 83, 1855-1862.

Thomas, J.B. \& Watson, E.B. (2012). Application of the Ti-in quartz thermobarometer to rutile-free systems. Reply to: A comment on: "TitaniQ under pressure: The effect of pressure and temperature on the solubility of Ti in quartz" by Thomas et al. Contrib Mineral Petrol 164, 369-374.

Thomas, J.B., Watson, E.B., Spear, F.S., Shemella, P.T., Nayak, S.K. \& Lanzirotti, A. (2010). TitaniQ under pressure: The effect of pressure and temperature on the solubility of $\mathrm{Ti}$ in quartz. Contrib Mineral Petrol 160, 743-759.

Ulrich, T., Kamber, B., Jugo, P. \& Tinkham, D. (2009). Imaging element distribution patterns in minerals by laser ablationinductively coupled plasma mass spectrometry (LA-ICP-MS). Can Mineral 47, 1001-1012.

Vasyukova, O.V., Goemann, K., MacRae, C.M., Wilson, N.C. \& Kamenetsky, V.S. (2013). Cathodoluminescence properties of quartz eyes from porphyry-type deposits: Implication to their origin. Am Mineral doi.org/10.2138/am.2013.4018.

Vazquez, J., Kyriazis, F., Reid, M.R., Sehler, R.C. \& Ramos, F.C. (2009). Thermochemical evolution of young rhyolites at Yellowstone: Evidence for a cooling but periodically replenished postcaldera magma reservoir. J Volcanol Geotherm Res 188, 186-196.

Wark, D.A., Hildreth, W., Spear, F.S., Cherniak, D.J. \& Watson, E.B. (2007). Pre-eruption recharge of the bishop magma system. Geology 35, 235-238.
Wark, D.A. \& Watson, E.B. (2006). The TitaniQ: A titaniumin-quartz geothermometer. Contrib Mineral Petrol 152, 743754.

WAtson, E.B. \& Harrison, T.M. (1983). Zircon saturation revisited: Temperature and composition effects in a variety of crustal magma types. Earth Planet Sci Lett 64, 295-304.

Watt, G.R., Wright, P., Galloway, S. \& Mclean, C. (1997). Cathodoluminescence and trace element zoning in quartz phenocrysts and xenocrysts. Geochim Cosmochim Acta 61, 4337-4348.

Watts, K.E., Bindeman, I.N. \& Schmitt, A.K. (2012). Crystal scale anatomy of a dying supervolcano: An isotope and geochronology study of individual phenocrysts from voluminous rhyolites of the Yellowstone caldera. Contrib Mineral Petrol 164, 45-67.

Wiebe, R.A., Wark, D.A. \& Hawkins, D.P. (2007). Insights from quartz cathodoluminescence zoning into crystallization of the Vinalhaven granite, coastal Maine. Contrib Mineral Petrol 154, 439-453.

Wilson, C.J.N., Seward, T.M., Allan, A.S.R., Charlier, B.L.A. \& Bello, L. (2012). A comment on: "TitaniQ under pressure: The effect of pressure and temperature on the solubility of $\mathrm{Ti}$ in quartz" by Jay B. Thomas, E. Bruce Watson, Frank S. Spear, Phillip T. Shemella, Saroj K. Nayak and Antonio Lanzirotti. Contrib Mineral Petrol 164, 359-368. 